\title{
Mississippi River Delta: Land Subsidence and Coastal Erosion
}

\author{
Kenneth R. Olson ${ }^{\circledR}$, Cory D. Suski \\ Department of Natural Resources, College of Agricultural, Consumer, and Environmental Sciences, University of Illinois, \\ Urbana, Illinois, USA \\ Email: krolson@illinois.edu
}

How to cite this paper: Olson, K.R. and Suski, C.D. (2021) Mississippi River Delta: Land Subsidence and Coastal Erosion. Open Journal of Soil Science, 11, 139-163. https://doi.org/10.4236/ojss.2021.113008

Received: February 4, 2021

Accepted: March 13, 2021

Published: March 16, 2021

Copyright (c) 2021 by author(s) and Scientific Research Publishing Inc. This work is licensed under the Creative Commons Attribution International License (CC BY 4.0).

http://creativecommons.org/licenses/by/4.0/

\begin{abstract}
The Mississippi River Delta is a major center for transportation, industry, human population and ecosystem services. Critical areas included energy production, navigation, fisheries, flood protection of coastal communities, and restoration of damaged habitats. Complex environmental management in a great river system requires broad-base complex science, engineering and monitoring. A major national and state objective has become the restoration of the Mississippi River Delta that is threatened by subsidence, flooding, storm surges, compaction, oil extraction and gas extraction. The primary objectives of the paper are to document the landscape and geological properties of the Mississippi River Delta which have contributed to the successful resource and economic development of a historically-rich region of North America and to document the natural resource and environmental risks to the Mississippi River Delta. Economic and urban development of the Mississippi River Delta by the oil and gas industry and creation of levees by the USACE has contributed to land subsidence problems. Environmental challenges include land subsidence as a result of the pumping of vast amounts of oil and gas, the lack of sediment deposition in the Mississippi River Delta as a result of a system of levees, coastal erosion impacts of hurricanes, disposal of untreated and treated wastewater, periodic flooding and water pollution.
\end{abstract}

\section{Keywords}

Atchafalaya River Basin, Fisheries, Hurricane Katina, Oil and Gas

Industry, Sedimentation

\section{Introduction}

The Mississippi River's major deltaic cycle began approximately 7000 years ago. The modern Mississippi River Delta was formed as the Mississippi River depo- 
sited clay, silt and sand along its banks and in adjacent basins. The Mississippi River Delta is a river-dominated delta system fed by the greatest river and tributary system in North America. The current bird foot-shaped delta (Figure 1) reflects the dominance of the river over other geologic and hydrologic processes. Before the levee system was completed in 1926, the Mississippi River avulsed its course every 1000 to 1500 years to find another and usually a shorter route to the Gulf of Mexico (Figure 2). Starting with early 1700s European settlement, humans have struggled with the delta's natural cycle of floods, transgression and progradation [1]. As a result of the influx of nutrient-rich sediments, the delta is a prime area for growing sugar cane (Saccharum officinarum) (Figure 3), cotton (Gossypium spp.) and indigo (Baptisia macrophylla).

The Mississippi River Delta, $2.2 \mathrm{~m}$ ha of land area on the southern coast of Louisiana along the Gulf of Mexico, stretches from Vermilion Bay on the west to Chandeleur Islands on the east (Figure 2). The Delta catchment basin drains $3,220,000 \mathrm{~km}^{2}$ of land between the Rocky Mountains and the Appalachian mountain ranges. The Mississippi River Delta, the $7^{\text {th }}$ largest river delta in the world, is an important coastal region in the US with $1.1 \mathrm{~m}$ ha of coastal wetlands (Figure 4) with $37 \%$ of estuarine marshes in the United States.

The primary objectives of the paper are: 1) to document the landscape and geological properties of the Mississippi River Delta which have contributed to the successful economic and resource development of a historically-rich region

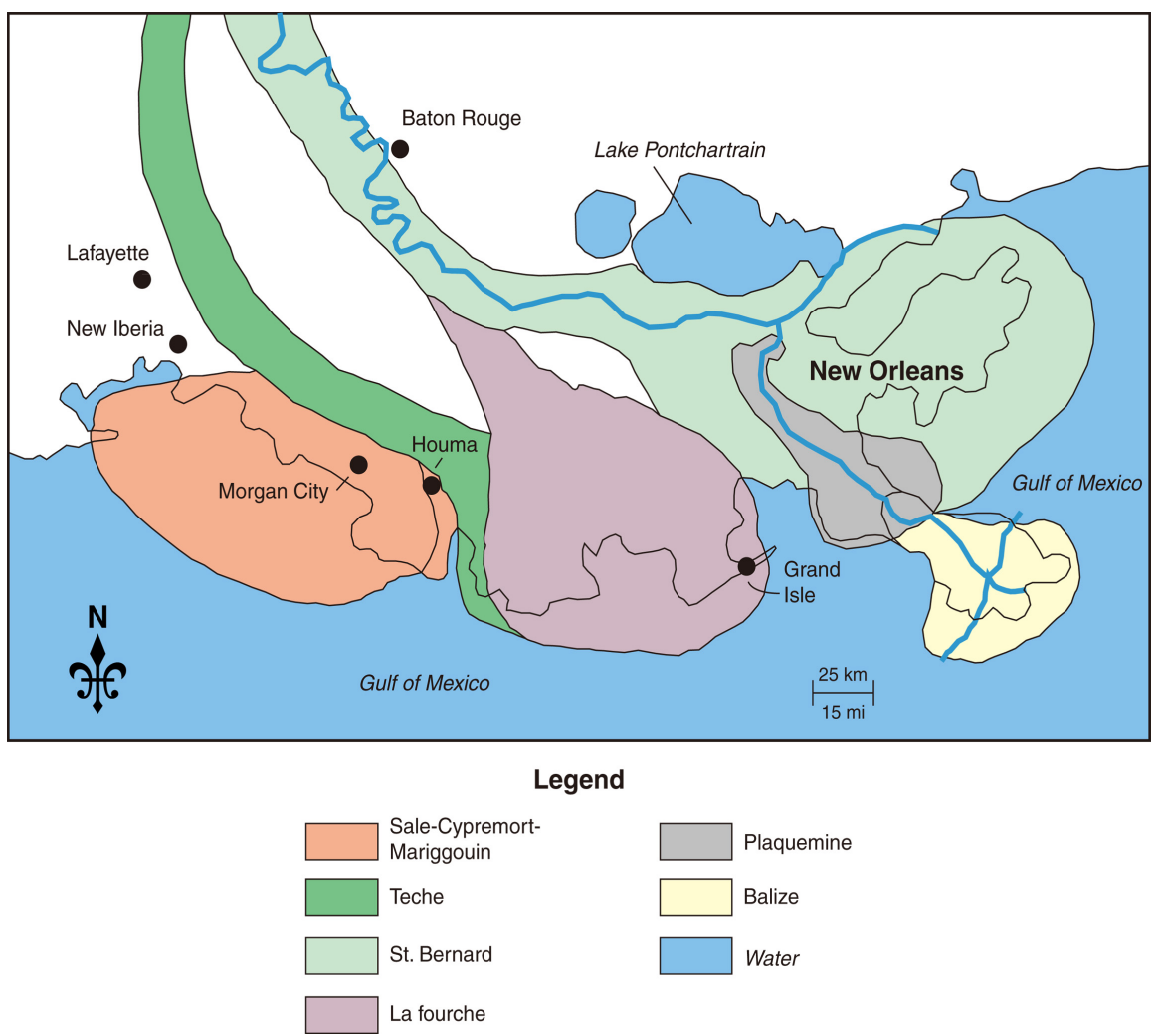

Figure 1. The six sub-deltas which form the current Mississippi River Delta Map by Mic Greenberg. 


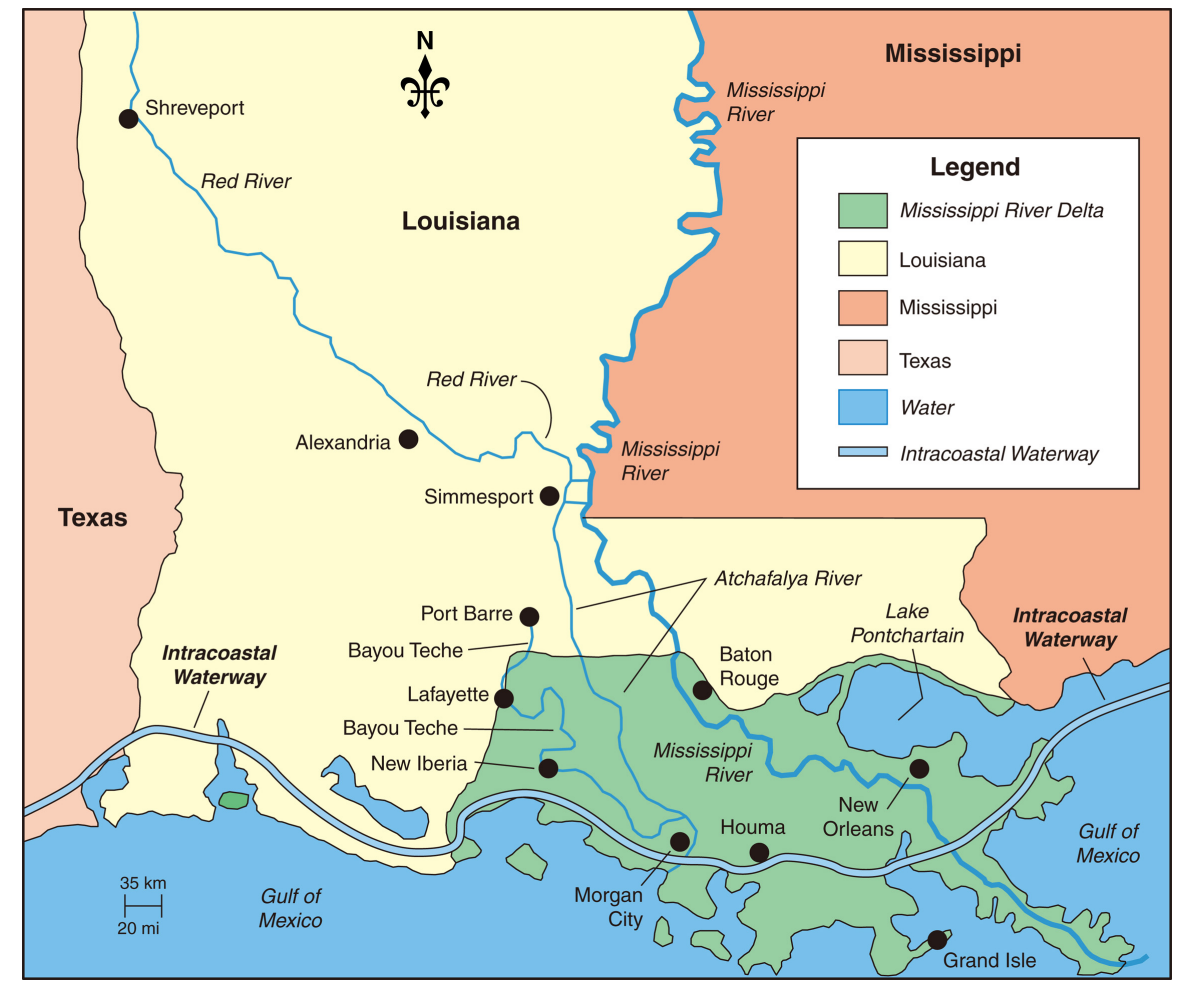

Figure 2. Location of the Mississippi River Delta Map by Mic Greenberg.

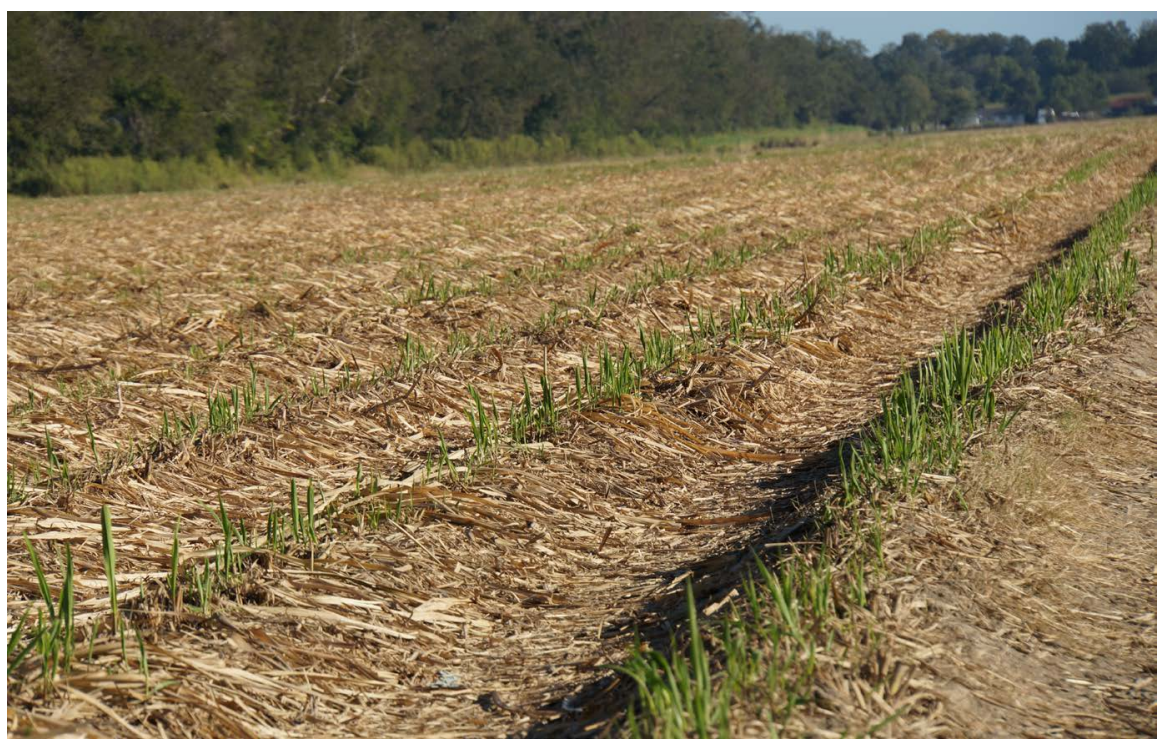

Figure 3. Sugar cane growing on ridges with a residue cover on the Mississippi River Delta.

of North America and 2) to identify the environmental and natural resource risks to the Mississippi River Delta. Environmental challenges include land subsidence as a result of the pumping of vast amounts of oil and gas (Figure 5), the lack of sediment deposition in the Mississippi River Delta as a result of levees, the settlement of millions of people on the Mississippi River Delta, compaction, navigation on the Mississippi River (Figure 6), disposal of untreated and treated 


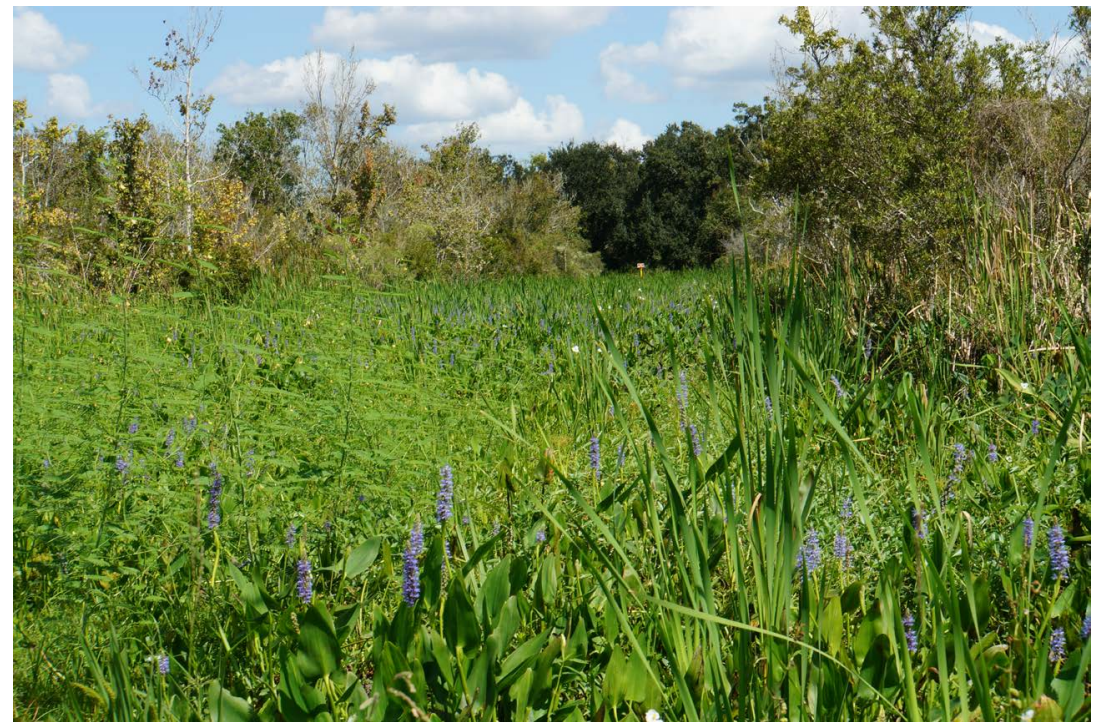

Figure 4. Wetland marshes along the Gulf of Mexico coastal shoreline photograph taken by Lois Wright Morton.

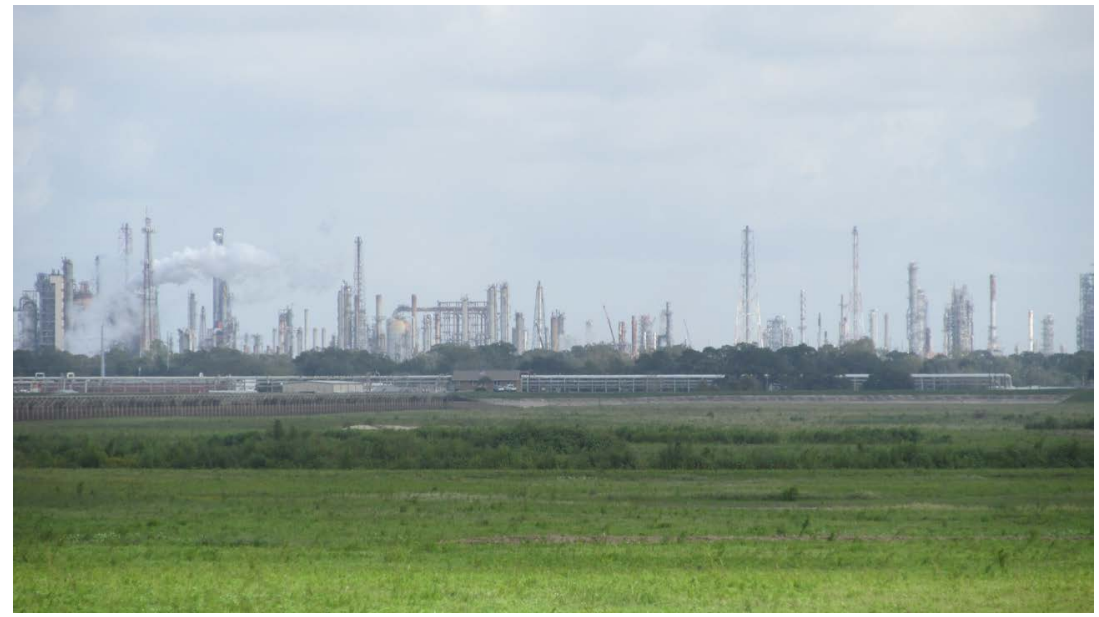

Figure 5. Picture of the oil and gas refineries on the Mississippi Delta.

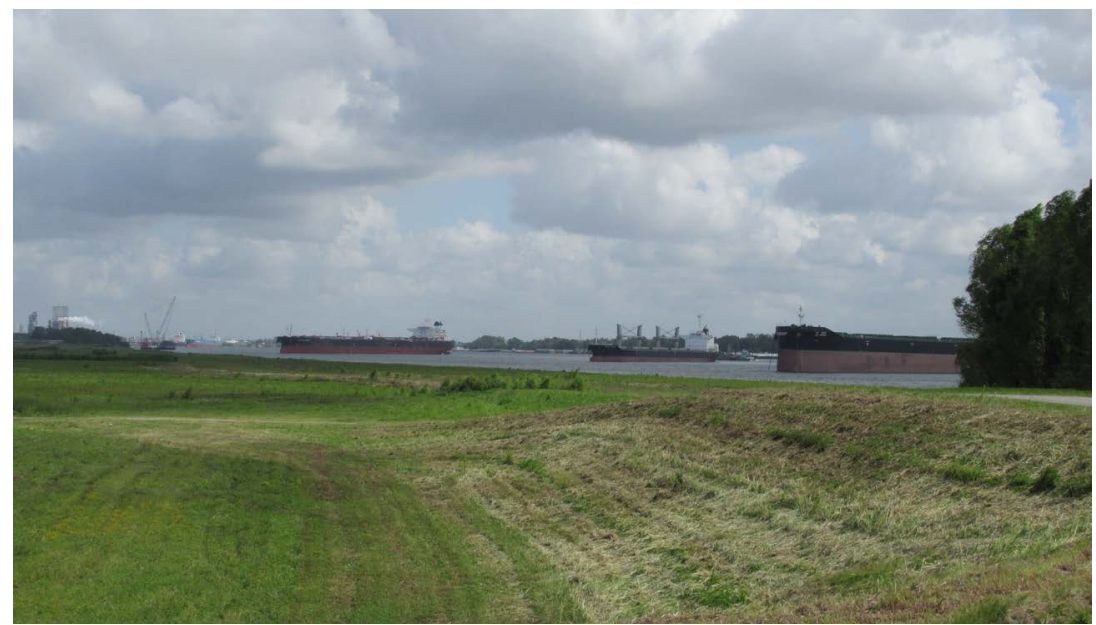

Figure 6. Ships on the Mississippi River near Lake Pontchartrain. 
wastewater, water pollution, the impact of hurricanes on coastal shore erosion, and periodic flooding (Figure 7).

\section{Site Location}

\subsection{Historical Geology of the Mississippi River Delta}

Holocene Mississippi Delta began to form approximately $5000 \mathrm{BCE}$ as the rate of sea-level rise slowed and was outpaced by the rate of sediment delivery to the basin [2]. The delta was comprised of smaller sub-deltas that overlapped over time [3]. Eventually, the Mississippi River Delta was formed by at least six delta complexes (Figure 1). The Mississippi River Delta complexes consist of smaller areas known as delta lobes, which include basins and other natural landscapes of the coastline. These are identified as Mariggouin, Teche, St. Bernard, La Fourche, Plaquemine-Balize and Atchafalalya and Wax Lake Outlet sub-deltas. After each deltaic cycle, which offered a shorter route for the Mississippi River to the Gulf of Mexico, the older delta lobe was abandoned. This cut off the primary supply of fresh water and sediments to an older lobe, where these sediments underwent compaction, subsidence and erosion.

The sub-deltas delivered their sediment load to the Mississippi River basin and built land through processes of pro-gradation into bay environments, aggradation by crevasse and overbank deposition. Sub-deltas were initiated with stream capture, which delivered both freshwater and sediment to new depo-centers and were ultimately abandoned as the depo-center changed positions in response to river changes in alignment [3]. The historic and prehistoric delta lobes of the Mississippi River Delta have influenced the formation of the Louisiana coastline and created over $1.6 \mathrm{~m}$ ha of coastal wetlands [4]. Periods of land

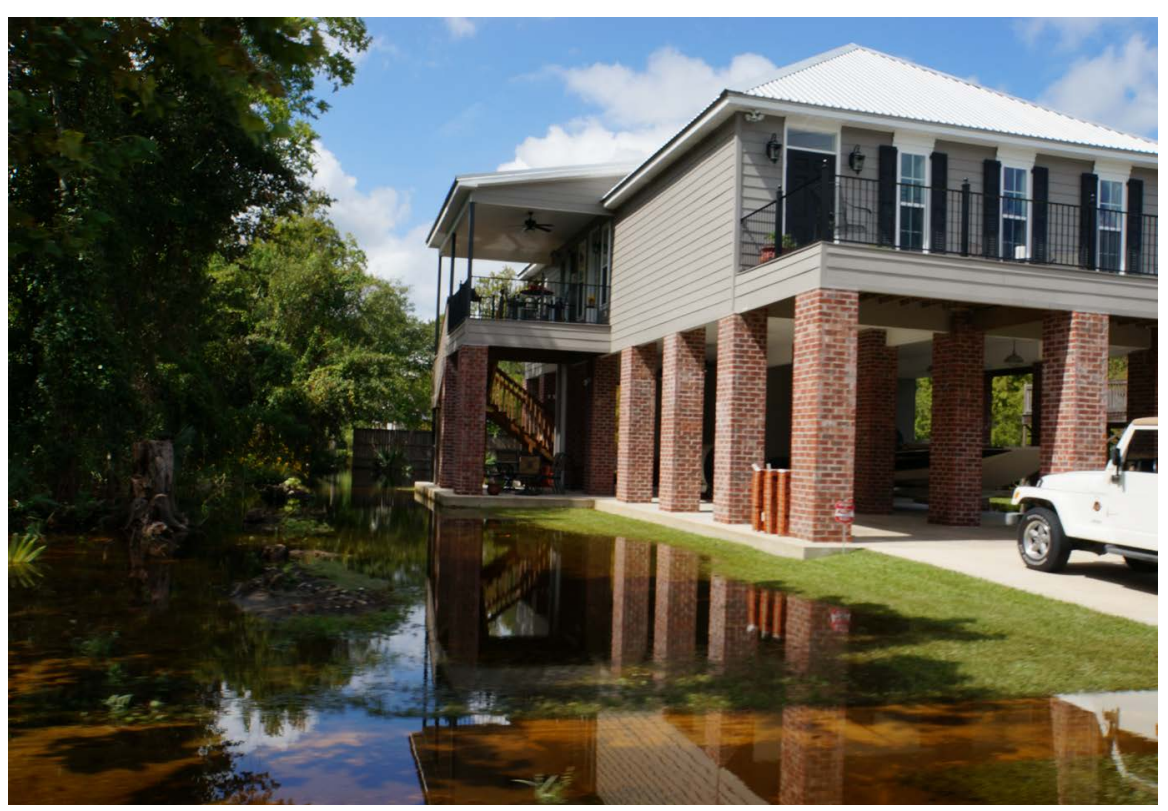

Figure 7. Flooding of a Louisiana city on the Lake Pontchartain photograph taken by Lois Wright Morton. 
loss and land building occurred in different areas of the delta as the river changed course and the natural flow of freshwater and sediments was altered.

In the natural deltaic cycle, the land (delta lobes) that form where the river meets the sea grows outward extending from the river as it overflows its banks and deposits sediment into the basins. This process is known as pro-gradation. Further from the river's mouth, the processes of subsidence, erosion and sea-level rise dominate and can result in coastal retreat. The creation of the Mississippi River Delta with integrated natural pro-gradation and degradation processes resulted in a mix of unique habitats, ecosystems and landforms.

The Atchafalaya River is the largest distributary of the Mississippi River and is also considered to be a significant part of the continual land-building process within the Mississippi River Delta. Around the middle of the twentieth century, the Atchafalaya River's tributary channel was formed as part of the Atchafalaya and Wax Lake lobes [5].

\subsection{Cultural History}

Native Americans called Paleoindiano settled on prairies west of the Teche region 13,500 years ago. Approximately 4500 years ago, other Native Americans constructed an earthen mound at Avery Island. At the start of the colonial era, two Native American tribes lived near Bayou Teche, the Opelousas and the Attahapas.

In 1519 Alvarez de Pineda of Spain discovered the Mississippi River Delta. In 1682, Robert Cavelier de La Salle claimed the Mississippi River Delta for France. In 1699 the French built the first fort at La Balize on Southeast Pass in Pass a Loutre to control passage from the Mississippi River into the Gulf of Mexico.

The first recorded attempt to control the Mississippi and tributary landscapes occurred in 1717. A deep water port, New Orleans, was established by the French on the Mississippi River about $80 \mathrm{~km}$ up river from the current Gulf of Mexico. The original settlement had 14 city blocks with drainage ditches around each block and was the first recorded attempt to control the landscape. The first levee was along the bank of the Mississippi River may have been erected in 1718, but was never confirmed. Documented levees were built in 1722 by the French. These levees were $1.2 \mathrm{~m}$ high earthen mounds that began a 300-year history of combating high water with embankments. The levees were sustained by private landowners, who used state prisoners, slaves and poverty stricken Irish immigrants to perform the deadly work. The New Orleans settlement was prone to periodic flooding by the Mississippi River, had poorly-drained soils, unfavorable topography, and was only a few feet above the sea. The settlement was on the deltaic floodplain of the Mississippi River, which was settling at a rate of between 0.6 to $3 \mathrm{~m}$ per century [1].

The original unit, which became the US Army Corps of Engineers (USACE), was established on June 16, 1775. The Continental Congress organized the Army with a chief engineer. General George Washington's first Engineer was Colonel 
Richard Gridley. A separate Corps of Engineers was officially established in 1779 by President Thomas Jefferson. In 1803, the US acquired New Orleans and 2,144,000 ha of land mostly located in the Mississippi River Valley from the French [1]. The $\$ 15$ million land acquisition became known as the Louisiana Purchase. The delta became a significant part of farming industries (Figure 8). Navigation and trade on the Mississippi River increased after the Civil War, and this economic development eventually moved into the Delta. During the 1870s, former Delta swamplands were converted to fertile farmlands via levee construction. Timber companies harvest forests, and crop planters followed, to capitalize on new agricultural opportunities. Railroads entered the Delta replacing steam boats as the primary means of transporting crops and produce. Vast gas and oil deposits brought further environmental and economic changes in the Delta. The openings of the Panama Canal in 1914 increases the Mississippi River Delta traffic. Shipping and commercial and local fisheries continued to expand.

The Mississippi River Delta has become home to 2 million people. The location of the Delta at the mouth of the Mississippi River allowed the area to be the Gateway to the United States and resulted in a mix of nationalities creating the diversity of the region. The French were Louisiana's first $18^{\text {th }}$ century colonists who were later joined by the Spanish and the Acadian settlers. By the $19^{\text {th }}$ century, European immigrant groups included the German, Sicilian and Irish. Later the African, West Indians and Native Americans were added to the mix. The combination of these groups over time created the unique culture found in the Mississippi River Delta. Two unique groups were Creoles and Cajuns. Cajuns refer to a white, black or mixed-race native of Louisiana [6]. They were the offspring from the union of various ethnic groups. Creole populations before 1803 were typically born of French and/or Spanish parents who kept their European characteristics and cultures.

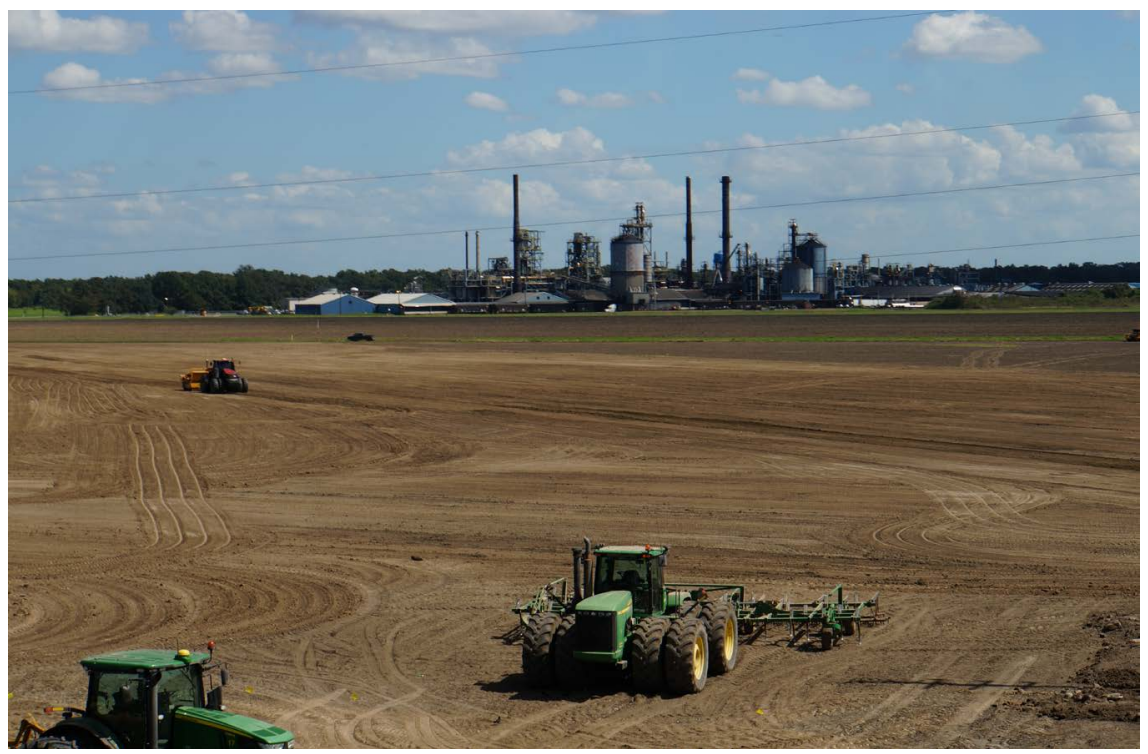

Figure 8. Agriculture cultivation with gas plant in the background on the Mississippi River Delta photograph taken by Lois Wright Morton. 
Many early Acadians came from the Centre-Quest region of France, located on the Atlantic Coast around Poitou. They left for the new world in the 1600s to escape from excessive taxation under feudal overlords, disease, famine, drought, and religious warfare. The Acadians settled in the present-day Maritime Provinces of Canada [7]. They called their new home Acadia and lived there for over 100 years on the frontier as farmers, hunters, fur trappers, and fishers. Unfortunately, the Acadians occupied land strategically important to the warring British and French empires. In 1710 the British seized Acadia, renamed it Nova Scotia (New Scotland), and, 45 years later, began to expel the Acadian population by force. According to estimates, 15,000 to 18,000 Acadians lived in Nova Scotia prior to the 1755 expulsion, and as many as 10,000 died from starvation, neglect, exposure, disease, and violence at the hands of the British [6]. Of the survivors, about 3000 exiles made their way to Spanish-held Louisiana between 1764 and 1788. The Spanish administrators wanted non-English settlers as buffers against British encroachment.

In 1762 France choose to cede the unprofitable colony, including Teche, to Spain. The French government offered large land grants to their colonial officers in lieu of costly transport back to Europe. One officer, Antoine Bernard Dauterive, received approximately 800 ha on both sides of the Bayou Teche (Figure 2). In 1775 Dauterive and other land-owning partners used their properties along the Teche in a novel entrepreneurial scheme. They brought in 200 French-speaking Acadian exiles and a herd of semi-domesticated Spanish longhorn cattle to be managed by the Acadians. Many of these exiles and their offspring began to intermarry with other ethnic groups on the frontier, and evolved into a vital new ethnic group: the Cajuns.

\subsection{Bayou Teche}

The Bayou Teche begins in Port Barre and flows south to meet the Lower Atchafalaya River at Patterson (Figure 2), and was the primary means of transportation during the Acadian migration. The Bayou Teche is a $200 \mathrm{~km}$ long waterway of cultural significance in southcentral Louisiana in the USA. Bayou Teche was the Mississippi River's main stem when it developed a Delta segment about 4500 to 2800 years ago (Figure 1). The Mississippi River's deposits of silt and sediment caused the river to change its course every thousand years. This natural process is known as deltaic switching.

Bayou Teche is a channel carved out by the Mississippi River approximately 3800 to 5500 years ago. When the Mississippi River moved east, the Red River occupied the channel (Figure 2). About 2000 years ago, the Red River was intercepted by the Mississippi River, which then drained to the Mississippi RiverDelta leaving behind the Bayou Teche and Atchafalaya River channels. The modern-Teche has 3 natural levees-its own present-day levee, a steep narrow inner relic levee of soil deposited by the Red River and the wide, gently sloping levee of brown and gray alluvium left by the Mississippi River. 
During the American Civil War (1861-1865), four Federal gunboats with twenty-seven guns traveled up the Teche in November of 1862 and engaged a modified Confederate gunboat that was originally a steam boat. These 4 federal gunboats later re-engaged the Confederate gunboats on January 14, 1863, and later in 1864 and 1865.

The almost complete obstruction of Bayou Tech occurred by 1868 and impaired navigation, commerce and agriculture. Restoration of the Bayou Teche was started in 1869 by the State of Louisiana, which provided $\$ 30,000$ to improve impaired navigation, commerce and agriculture. The USACE took over the process by 1870 .

\subsection{The 1927 Major Flood}

By 1926, the USACE had built levees on all the bottomlands between the Gulf of Mexico and Cairo, Illinois. The flood of 1927 flooded most of the Teche area except for the ridge west of Jeanerette and Baldwin, and natural levees on Teche Ridge, Leonville, Arnaudville, Breaux Bridge Parks, St. Martinville, Franklin and Teche Ridge (Centerville, Patterson and Barwick). Bayou Teche suffered under the combined weight of poverty, disease, violence and flooding.

After levees were built along the Atchafalaya River and tributaries in the 1930s, rice farms (Figure 9) along the bayou suffered a drastic reduction in fresh water. Between 1976 and 1982, the USACE built a pump station at Krots Springs to pump water from Atchafalaya to Bayou Coustableau.

In the 1940s, the USACE completed 3 large projects: 1) the West Atchafalaya Basin Protection levee, 2) the Charenton Drainage and Navigation canal and 3) Wax Lake Outlet. All were created in response to the Flood of 1927 and the series of Flood Control Acts passed by Congress to address future flood disasters. The West Atchafalaya Basin Protection ran 207 km from Avoyelles Parish down

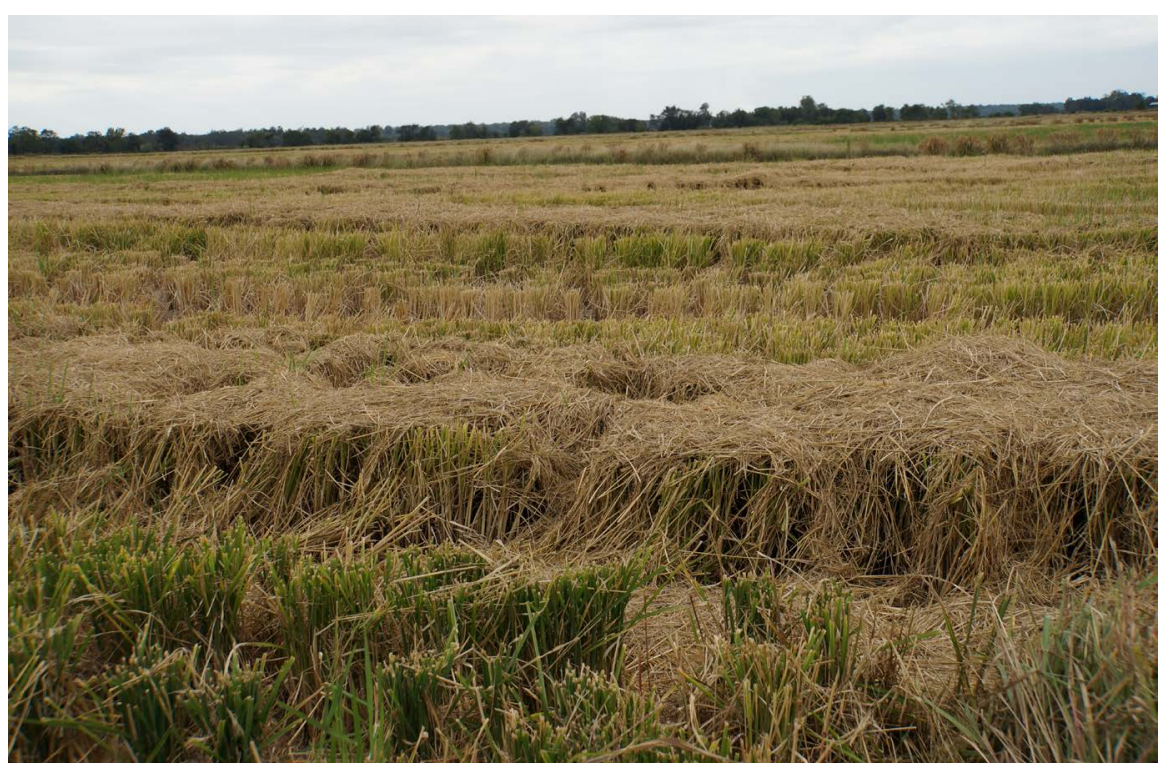

Figure 9. Harvested rice field in the Mississippi River Delta. 
to headwaters of the Teche, then south between the bayou and Atchafalaya swamp, and for a few miles past the bayou's mouth at Patterson (Figure 10). The huge West Atchafalaya basin berm was large enough to support a gravel road and changed the Teche by separating the bayou from its important fresh water sources including the Atchafalaya River, the Red River and the Mississippi River. It also blocked Lake Daulerive and Lake Fausse Point from discharging seasonal rainwater into the Atchafalaya Basin.

\subsection{Delta Today}

Louisiana's wetlands are one of the US's most important and productive natural assets consisting of natural levees, barrier islands, swamps, forests (Figure 11)

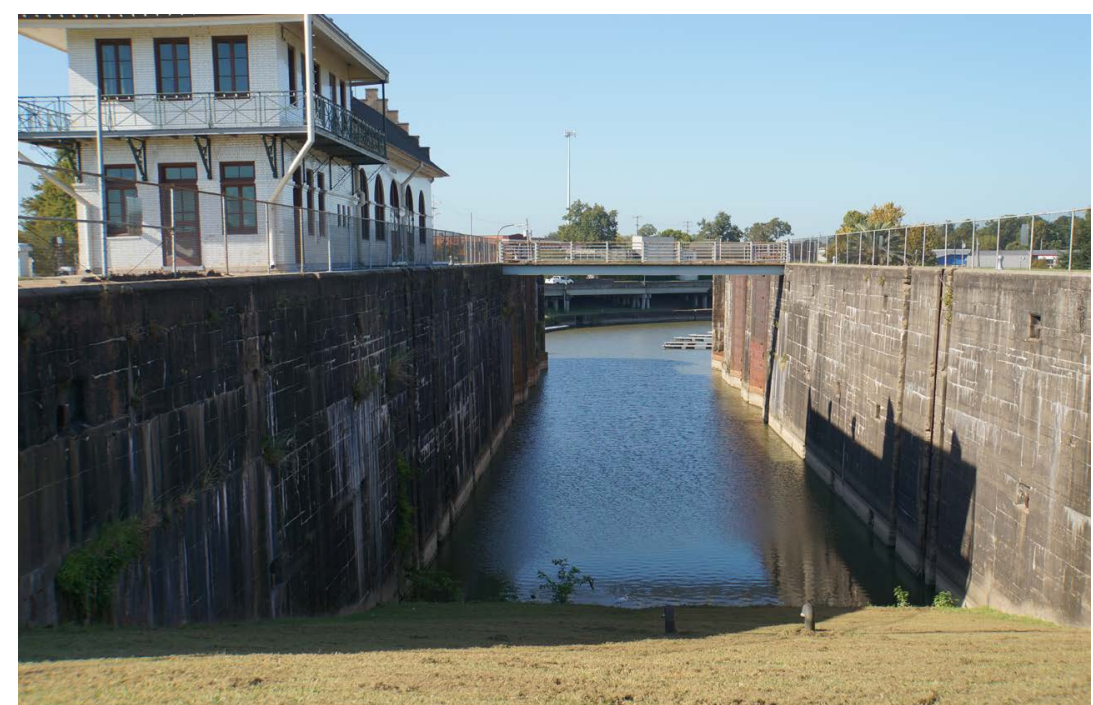

Figure 10. Lock on Touche waterway west of the Mississippi River photograph taken by Lois Wright Morton.

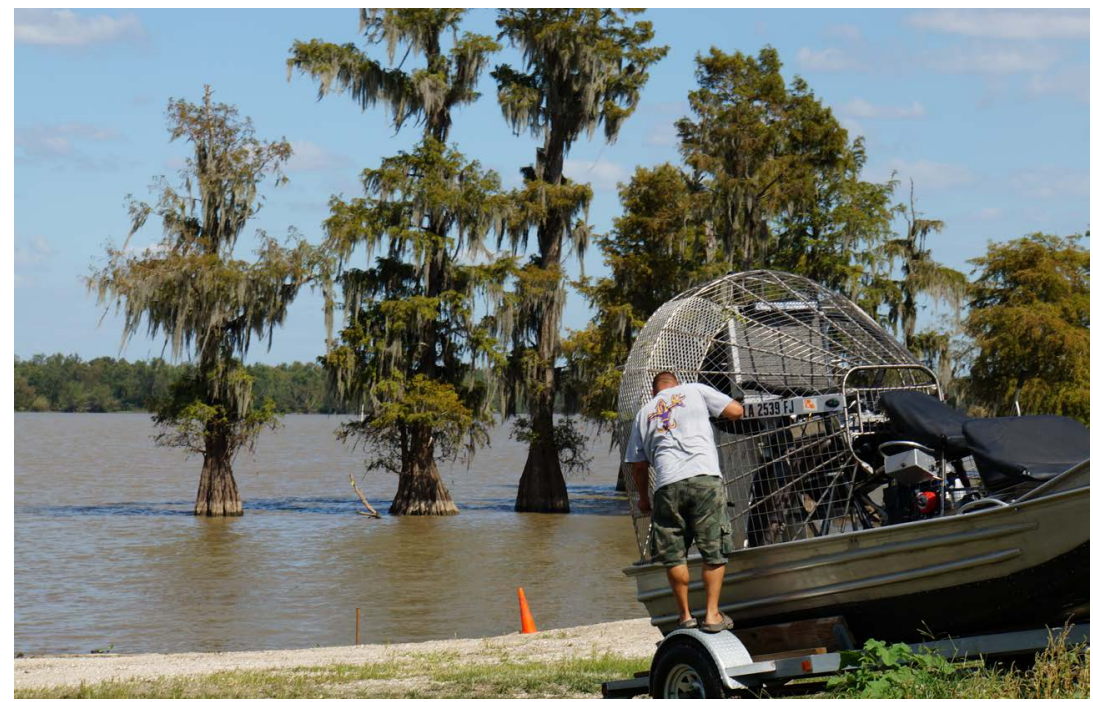

Figure 11. Bald cypress plus airboat being put into the water on the Atchafalaya River in Louisiana. 
and fresh, brackish and saline marshes. The region is also home to complex ecosystems and habitats. The Mississippi River Delta also provides numerous economic benefits and resources. These vital resources are at constant risk of being lost with the continual land loss and decreasing size of natural coastal areas. The Mississippi River Delta has a strong economy, which relies on oil, gas, shipping industries, tourism (Figure 12) and recreational activities such as fishing (Figure 13), wildlife watching, hunting and commercial fishing.

The oil and gas industry (Figure 14) employs $1 / 6^{\text {th }}$ of the Louisiana workforce. Port Fourchon in southern Louisiana, services $90 \%$ of the offshore oil rigs in the Gulf of Mexico, which provides 16\% - 18\% of the United States oil supply. Five of the US's largest ports are located in Louisiana, including Baton Rouge and

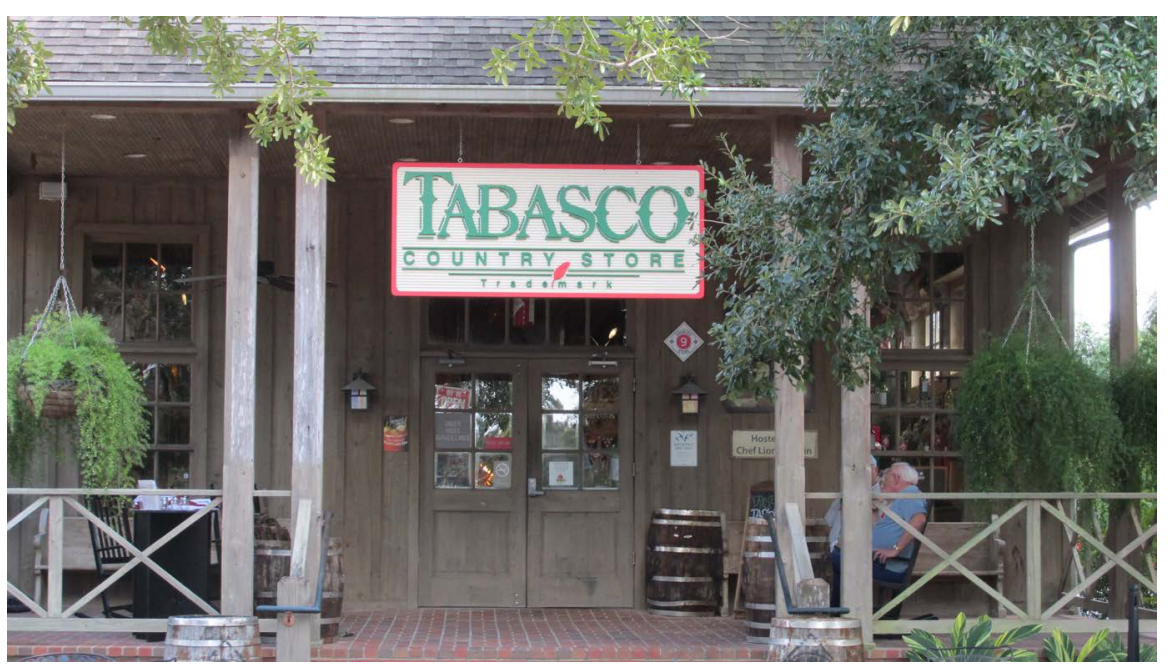

Figure 12. Tabasco headquarters on a sand boil is a tourist attraction on the Mississippi River Delta in Louisiana photograph taken by Lois Wright Morton.

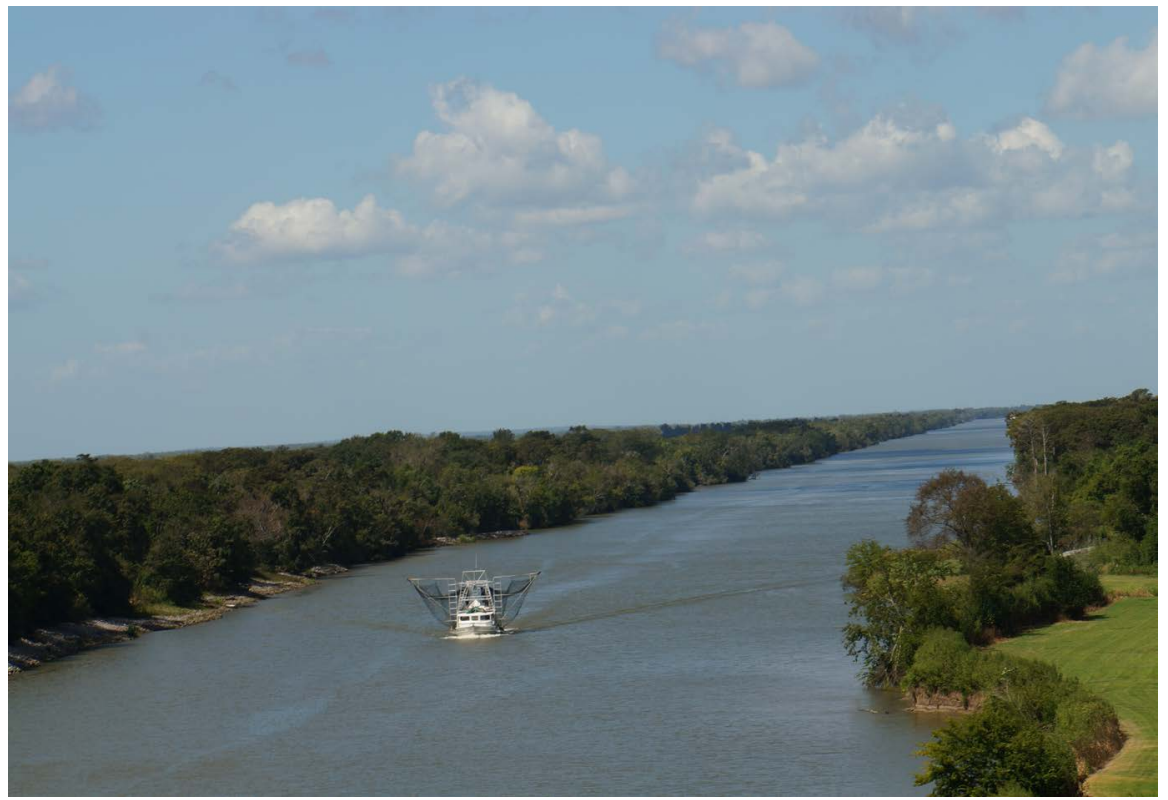

Figure 13. Fishing boat on the inland waterway. 


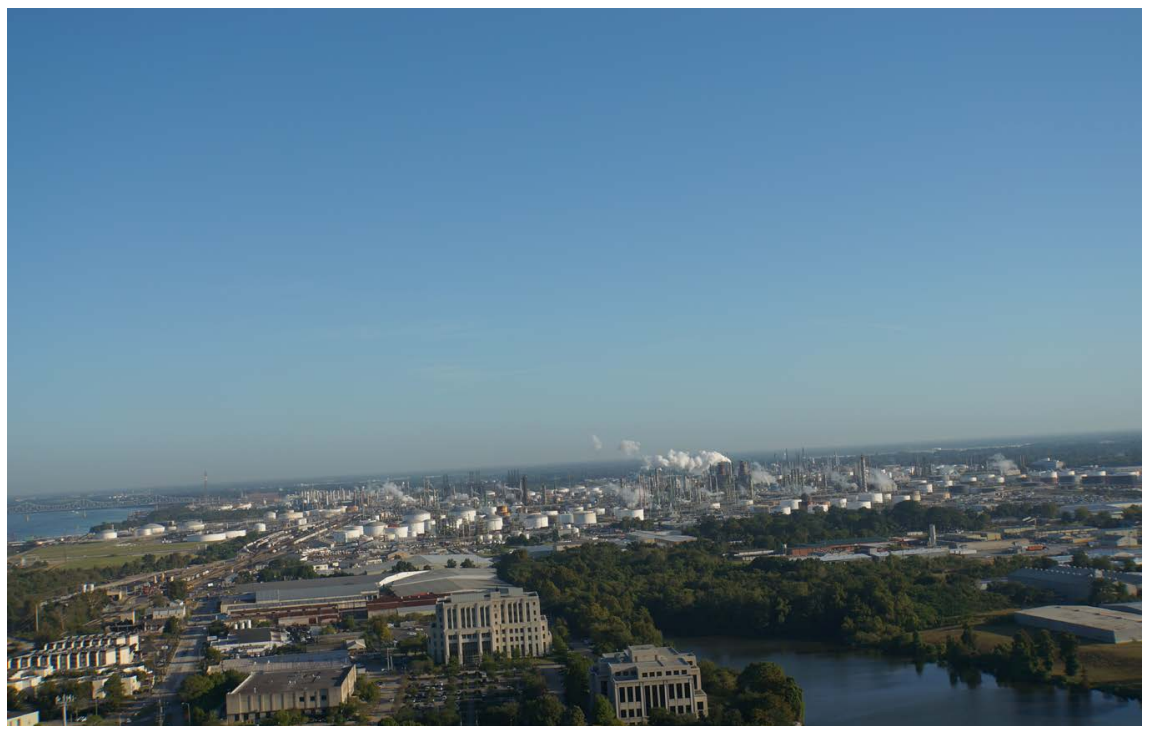

Figure 14. Picture of the oil and gas refineries and the Mississippi River. The picture was taken from the observation deck on the Louisiana State Capital building photograph taken by Lois Wright Morton.

New Orleans. Louisiana's ports receive over $\$ 100$ billion per year in agricultural goods, chemicals, machinery, timber, coal and steel. Commercial and recreational fisheries are economically, culturally and historically significant along the Louisiana coast. The Gulf region provides 33\% of the nation's seafood harvest. Commercial fishing is a $\$ 2.4$ billion industry in the Gulf of Mexico with $3 / 4^{\text {th }}$ of the fish caught coming through Louisiana ports. Louisiana tourist activities include recreational fishing, hunting and swamp tours as well as eating at local seafood restaurants. The Mississippi River Delta provides also provides a habitat for wildlife. The Mississippi Delta wetlands, marshes and barrier islands provide protection for coastal residents and communities from storm surge and flooding.

The Delta landscape includes saline and brackish marshlands, making up more than $13 \%$ of Louisiana's landmass or more than $1.2 \mathrm{~m}$ ha. Barrier islands protect Louisiana residents from hurricane storm surges and provide a home to many birds. The Atchafalaya Basin has the largest swamp within the Mississippi River Delta with $0.4 \mathrm{~m}$ ha of forested wetlands. Approximately $1 \mathrm{~m}$ ha of bottomland hardwood and maritime forests, coastal flat wood and coastal tall grass prairie have now been replaced by cattle ranching and sugar cane farming (Figure 3).

The Mississippi River Delta is home to a variety of mammal s including black bears (Ursus americanus), dolphins (Delphinidae delphis), minks (Neovision vison), beavers (Castor canadensis), armadillos (Dasypus novemcinctus) (Figure 15), foxes (Vulpes vulpes), coyotes (Canis latrans), hogs (Sus scrofa) (invasive species) and bobcats (Lynx rufus). Approximately 460 bird species have been recorded in Louisiana, with 300 of these found within the coastal wetlands. Delta wetlands provide fish and shellfish habitats. Almost all commercial fish and 


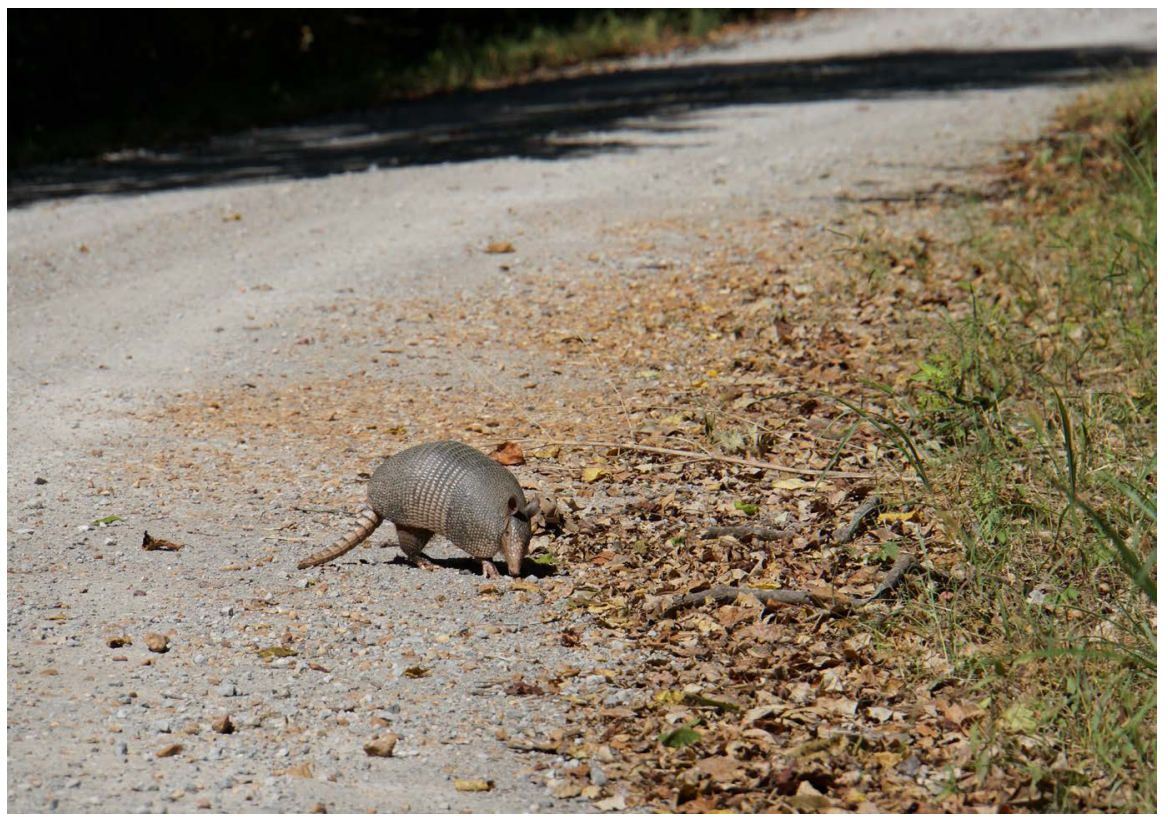

Figure 15. Armadillo in the Mississippi River Delta.

shellfish species spend time in coastal wetlands. Fish and shellfish species found include redfish (Sebastes fasciatus), flounder (Paralichthys lethostigma), blue crabs (Callinectes sapidus), shrimp (Caridea), catfish (Ictalurus punctatus) and largemouth bass (Micropterus salmoides).

Endangered and threatened species include: Kemp's Ridley Turtle (Lepidochelys kempii) and Piping plover (Charadrius melodus), and Louisiana black bear (Ursus americanus). Sediment deposition from the Mississippi river has resulted in both growth and retraction in landmass. Recently land loss processes have surpassed land-building [8]. Causes include hurricanes, climate changes and man's activities (Figure 16).

\subsection{Fisheries in the Mississippi River Delta}

The coastal areas of Louisiana support one of the largest commercial fisheries in the nation, employing over 30,000 people that capture millions of pounds of fish and shellfish, adding over 1.5 billion dollars in economic impact in 2017 (https://www.fisheries.noaa.gov/data-tools/fisheries-economics-united-states-int eractive-tool). Similarly, the recreational fisheries of the Gulf of Mexico region employed over 11,000 people providing over a billion dollars of economic impact to the state of Louisiana

(https://www.fisheries.noaa.gov/data-tools/fisheries-economics-united-states-int eractive-tool). The Mississippi River plays a large role in the success of this fishery. Nutrient inputs from the Mississippi River stimulate productivity in the marine environment that stimulates the food web, while plumes of freshwater from the Mississippi create diverse, dynamic habitats that provide habitat for a range of species. Coastal marshes and wetlands are important resident and nursery areas for fish [9] [10] [11]. 


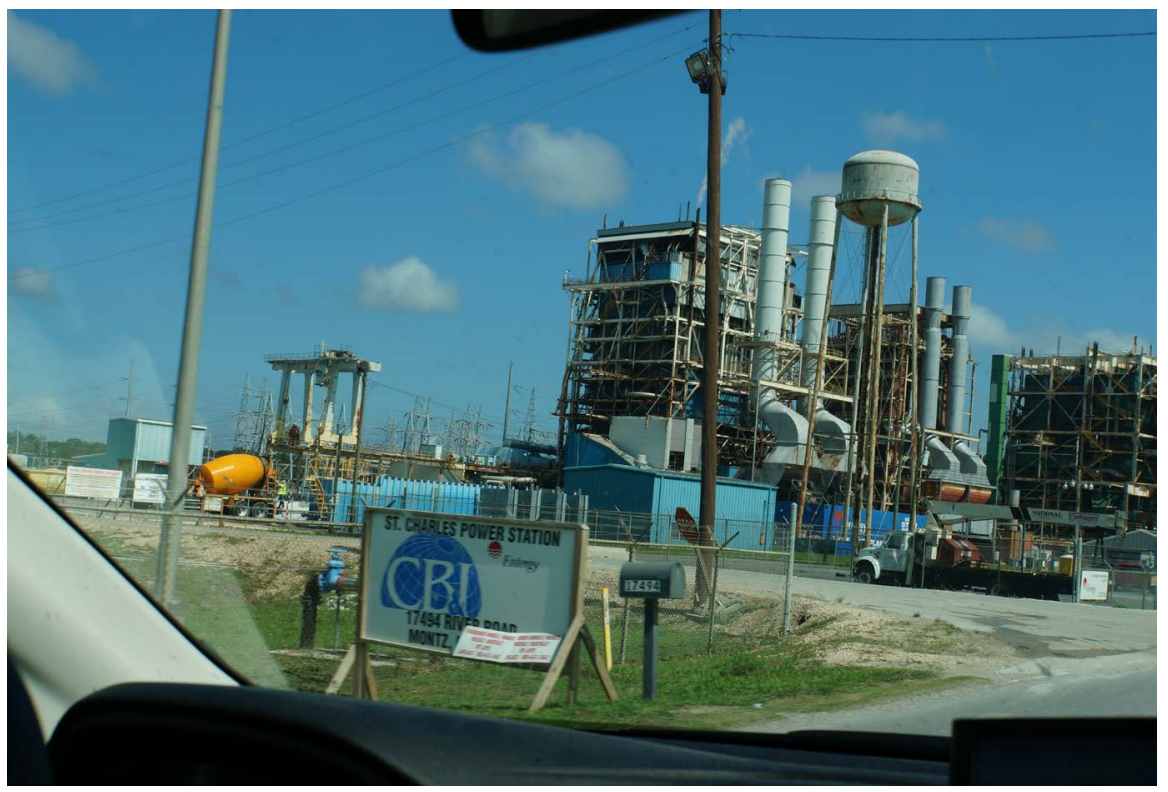

Figure 16. Man's activities including power generation on the Mississippi River Delta.

The changes to flow and sedimentation in the Mississippi River have resulted in a number of alterations to habitat for fish in the Gulf of Mexico. For example, wetland loss has reduced the amount of nursery habitat for many species, changes to the flow of the Mississippi River has changed salinity patterns, while excess nutrients have resulted in vast areas of low oxygen (hypoxia) that extend into the Gulf of Mexico [9]. Despite these changes, many commercial fisheries in Louisiana have remained stable over the past few decades, which is puzzling with the magnitude of degradation is considered [9] [12]. This trend may be occurring if changes in the population first occurred prior to the period of record for fisheries, if the edge of marsh habitat is the key factor influencing fish populations rather than total area, or if nutrient inputs that stimulate productivity to compensate for habitat degradation [9]. At present, links between the Mississippi River plume ecosystem and fisheries productivity need additional research to clearly identify trends and patterns and better inform predictions of future changes.

A challenge of restoration activities to restore coastal lands is the tradeoff between the long-term benefits of land building and potential short-term impacts to marine fisheries and populations of commercially important species. Freshwater diversions intended to deliver sediments and nutrients to help build wetlands can result in enhanced productivity for fisheries, but can also lead to eutrophication, algal blooms or hypoxia that can negatively impact marine fisheries [13]. For example, models suggest that the diversion of Mississippi River water into estuaries can alter salinity or chlorophyll concentrations that can cause the movement of fish to other habitats, often further offshore [11] [14], although this pattern is not universal [9]. Similarly, measures to reduce nutrient inputs into the Gulf of Mexico can result in reduced areas of hypoxia, but may 
negatively impact the productivity of marine ecosystems [9]. Research is therefore needed to define the optimum balance between the amount and timing of freshwater diversions, resulting in the maximum delivery of sediment while transporting a small amount of water [14].

\subsection{Natural and Anthropogenic Threats to the Mississippi River Delta}

Sediment is considered the key to the management of river-dominated coastal zones. Previously, most sediments from the Lower Mississippi River were transported into the deep water of the Gulf of Mexico [15]. However, 50\% of sediments load in the Lower Mississippi River is shunted through the South and Southwest passes, the major discharging outlets, after these sediments settle out of the river's water column and aggrade on the channel floor [16].

In the $19^{\text {th }}$ century, the Mississippi River channel dynamics shifted from a plentiful sediment supply to a supply-limited system. This shift occurred between Cairo (Illinois) and the confluence of the Mississippi and Ohio rivers, adding to the levees that increased velocities and limited overbanking which enhanced sediment export. During the middle part of the $20^{\text {th }}$ century the river was in an erosive site [17] but now is a dynamic equilibrium or aggrading (adding sediment). Shoaling, where a river channel becomes shallower, is occurring. Shoaling increases when sea levels rise and where the Mississippi River slope is reduced, or if changes in the volume of water carried by the river's distributaries occur. Both could affect navigation and commerce.

Coastal restoration plans include diverting part of the river flow to bring freshwater and new sediments to the subsiding basin [18] [19]. Flow through gated, controlled diversions can optimize land building and reduce adverse impacts such as shoaling and/or eutrophication. River diversions are proposed in Louisiana's coastal plan [20].

Subsidence is a significant threat to the Mississippi River Delta. In the absence of sediment inputs, the Mississippi River Delta subsidence is occurring at a greater rate than for other deltas in the United States. The subsidence rate may be further exacerbated through fluid extraction by the oil and gas industry (Figure 17). Storms and hurricanes are natural threats to the Delta. The first line of protection for communities and cities from hurricanes and storm surges are the coastal wetlands and barrier islands. As these landscapes weaken, the coast is more vulnerable to flooding and strong winds. Permanent loss of $518 \mathrm{~km}^{2}$ of wetlands occurred during the Katrina and Rita hurricanes.

Sea level rise in combination with saltwater intrusion, subsidence, hurricanes and storms has resulted in coastal erosion. Lack of sediments into these flooded wetland areas also accelerates the rate at which sea-level rise rate which affects the region [8]. The same combination of events is occurring in the Mekong Delta [21]. As global sea levels rise, the Mississippi River Delta areas that experience subsidence may flood and become open water (Figure 18). The levees, floodways, and basin and channel improvements were created to improve flood 


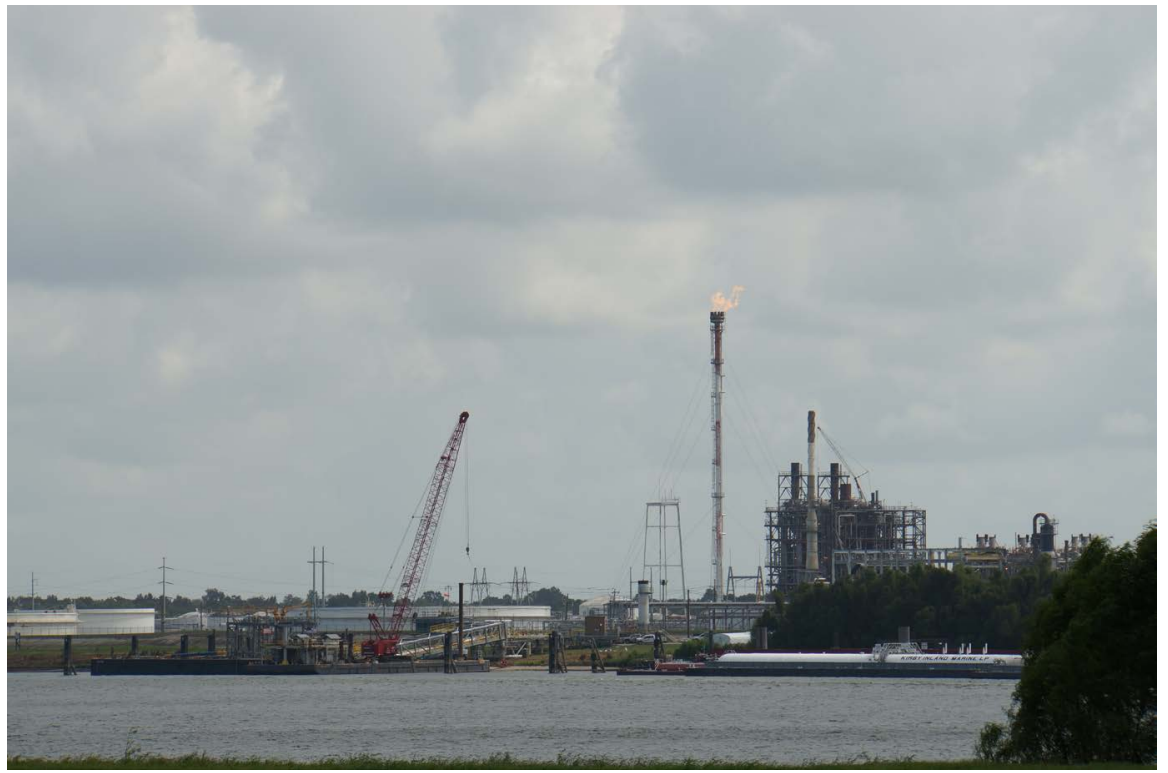

Figure 17. Gas plant on the Mississippi River Delta.

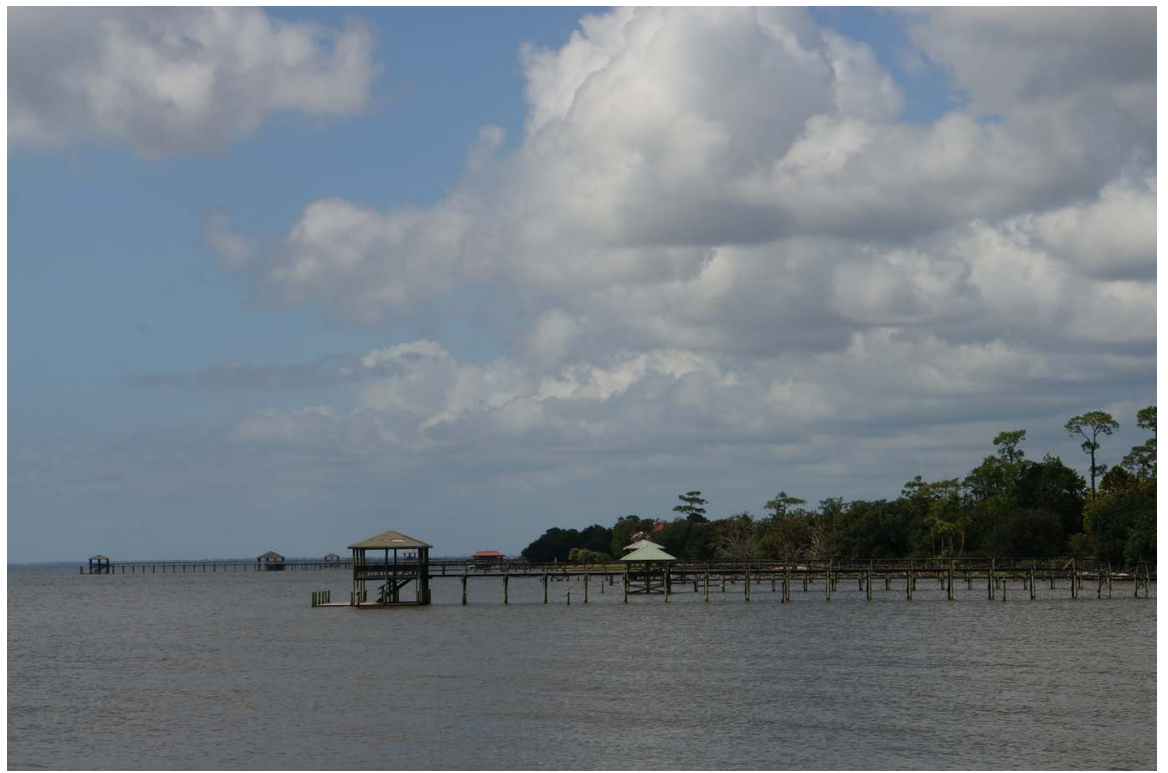

Figure 18. Picture of area piers along the Gulf of Mexico with coastal erosion.

protection for residents (Figure 19), agriculture (Figures 20-23) and communities, and has been effective. However, this protection has come at a high environmental cost for the delta's natural landscape and ecosystems (Figure 24) as the levees serve as the link between the river and surrounding wetlands. The river carried freshwater and sediment that is needed for land growth and in the delta, but the levees block the process and cut off the deposition of sediment in most of the delta. Since the 1950s, ten major navigation canals (Figure 13) and more than $14,970 \mathrm{~km}$ of pipelines were placed in the Delta. The impact of pipeline placement and dredging results in the direct loss of wetlands and accounts for 30 to 59\% of Louisiana's wetland loss from 1956 to 1978. 


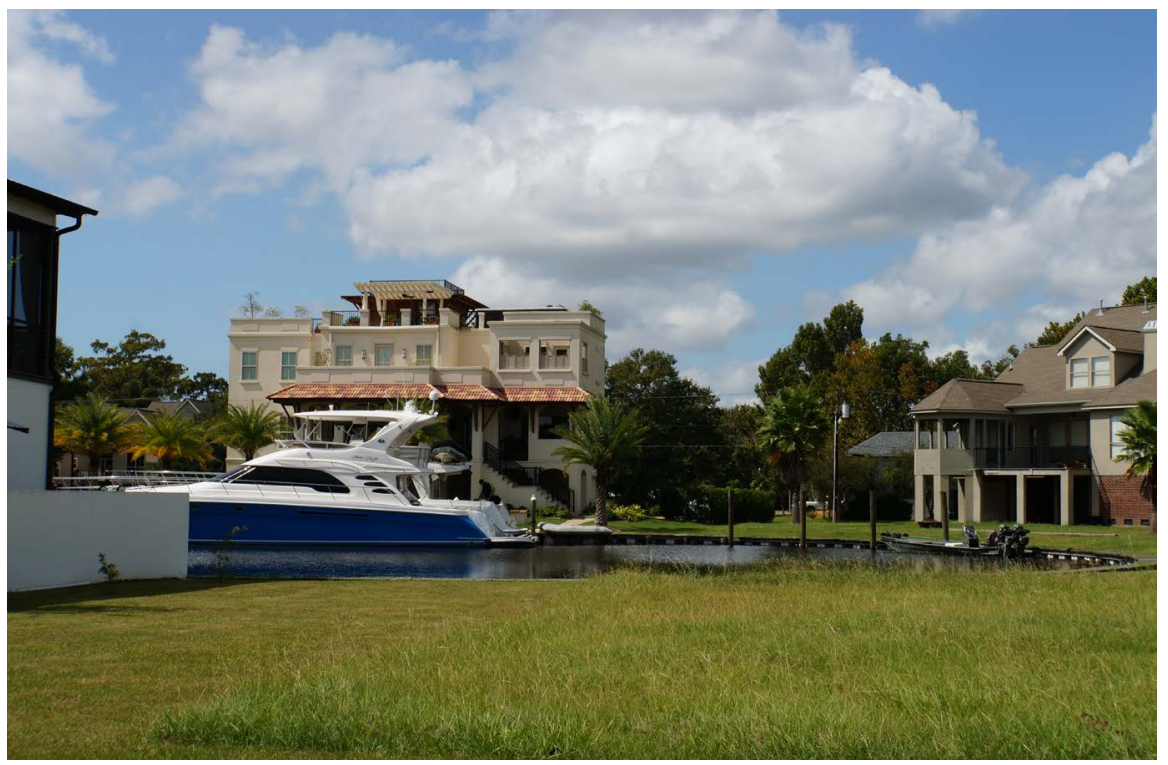

Figure 19. Boats and homes on Lake Pontchartrain.

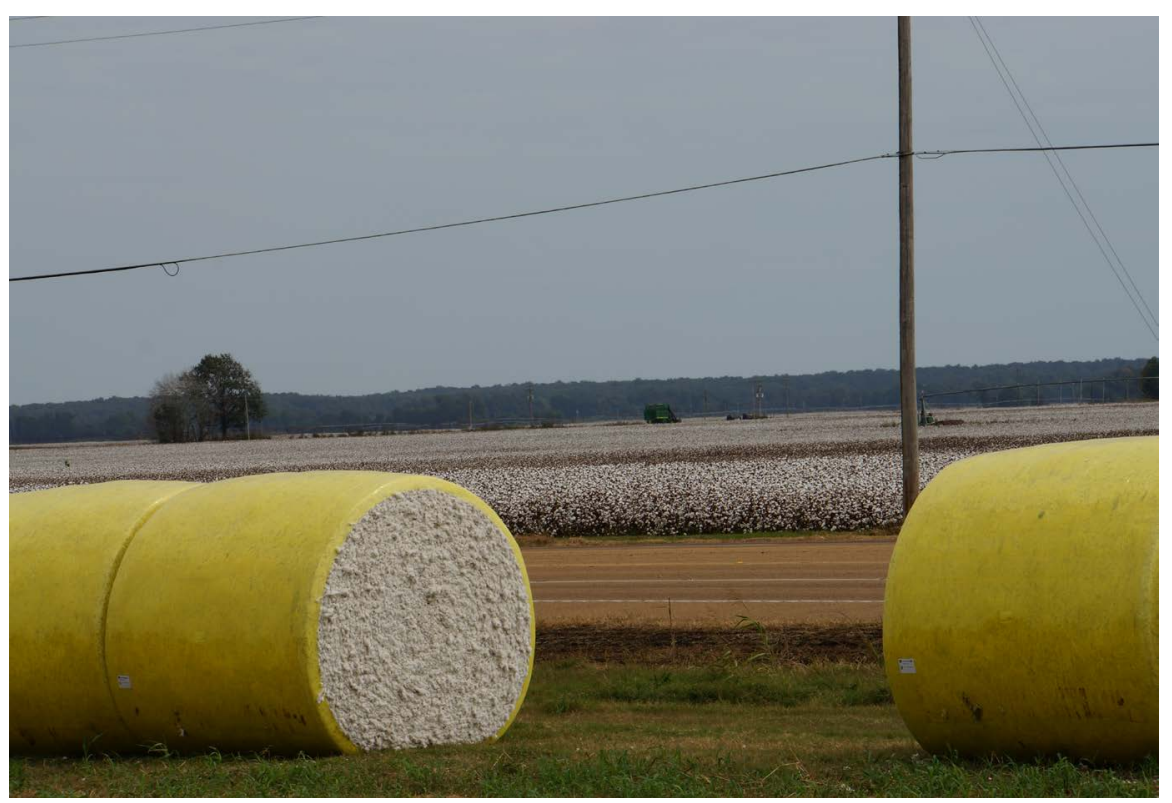

Figure 20. Cotton fields plus bales of cotton on the Mississippi River Delta photograph taken by Lois Wright Morton.

\subsection{Mississippi River Delta Restoration}

During the past 10 to 20 years a number of steps have been taken to increase the resiliency of coastal Louisiana. It took thousands of years to build the Mississippi River Delta, but the land loss is now happening at a much faster pace. Research is occurring to find feasible and effective projects to mitigate additional land loss and accelerate the delta rebuilding processes. By 2100 , as much as 10,000 to $13,000 \mathrm{~km}^{2}$ of the Mississippi River Delta may be lost or submerged.

After Hurricane Katrina, the Mississippi River Gulf Outlet Canal caused the USACE to develop an ecosystem restoration plan that included closing the 


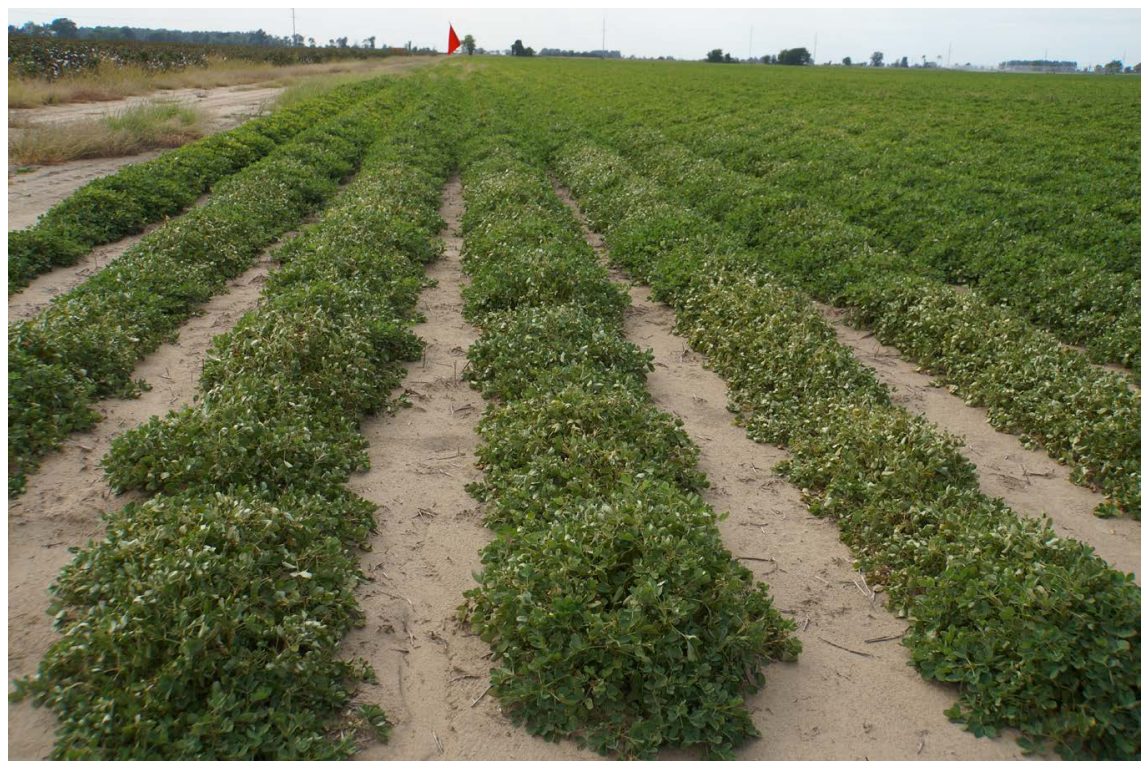

Figure 21. Peanut field in on the Mississippi River Delta.

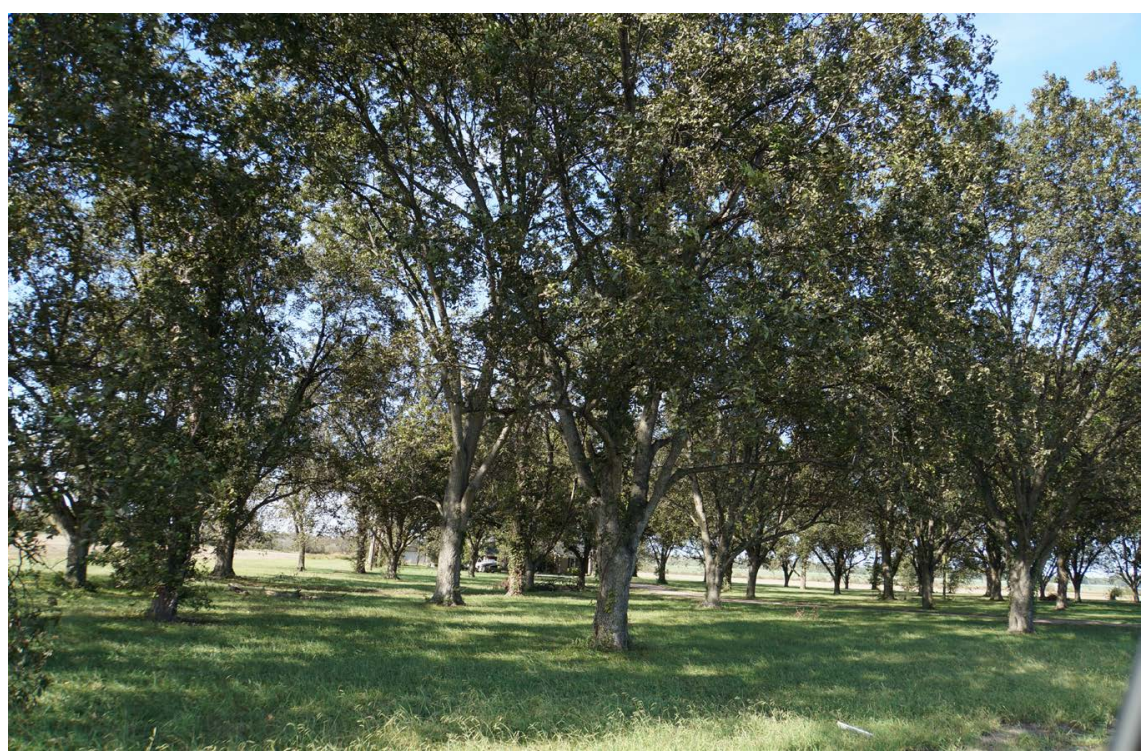

Figure 22. Large pecan trees in Louisiana and on the Mississippi River Delta photograph taken by Lois Wright Morton.

channel. The plan [22] included habitat rebuilding through a marsh, swamp, oyster reef, and wetland restoration. Freshwater diversions and construction of other structures were designed to fortify the coastline [23] [24].

The natural hydrology of the delta is disrupted by the dredging process. Canals and pipelines have increased erosion and degradation of the Mississippi River Delta by allowing salt water penetration into freshwater wetlands and contributing to creation of open water areas. The dredging, along with oil and gas development (Figure 25) in the Delta, affects the quantity of water, change the hydrology of the wetlands by depleting nutrient and sediments necessary for the health and survival of these areas. 


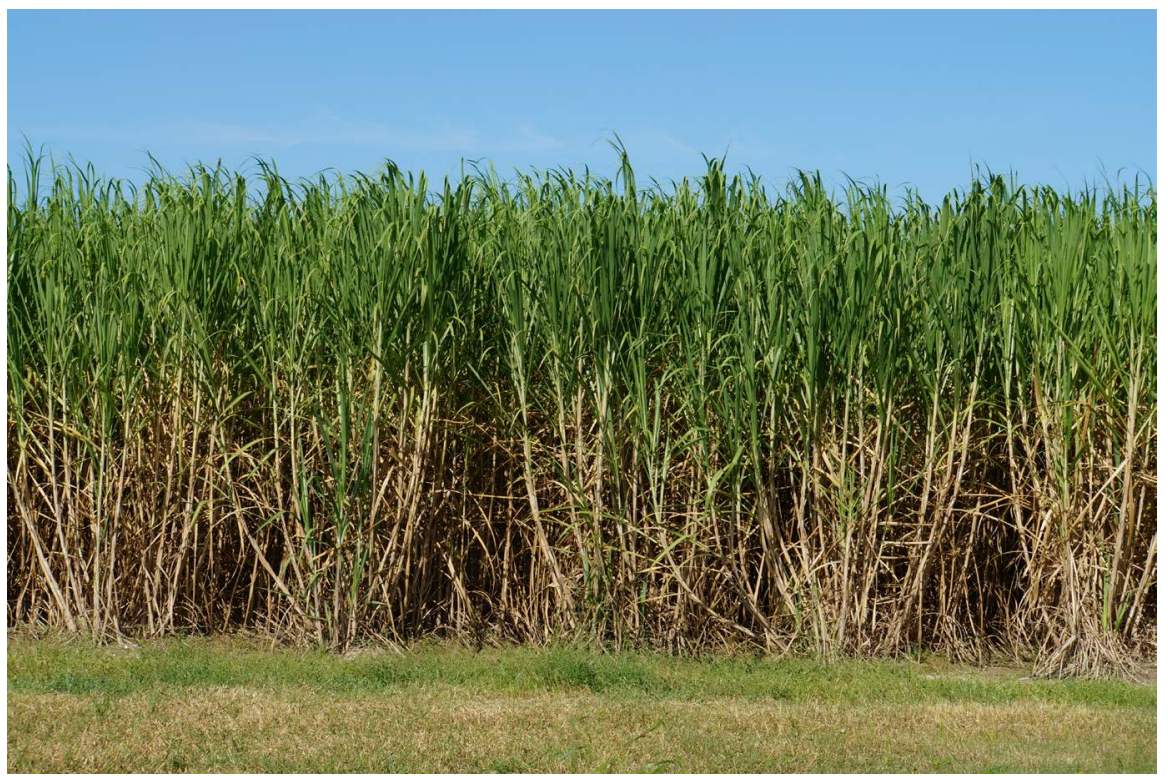

Figure 23. Mature sugarcane field ready for harvest in Mississippi River Delta.

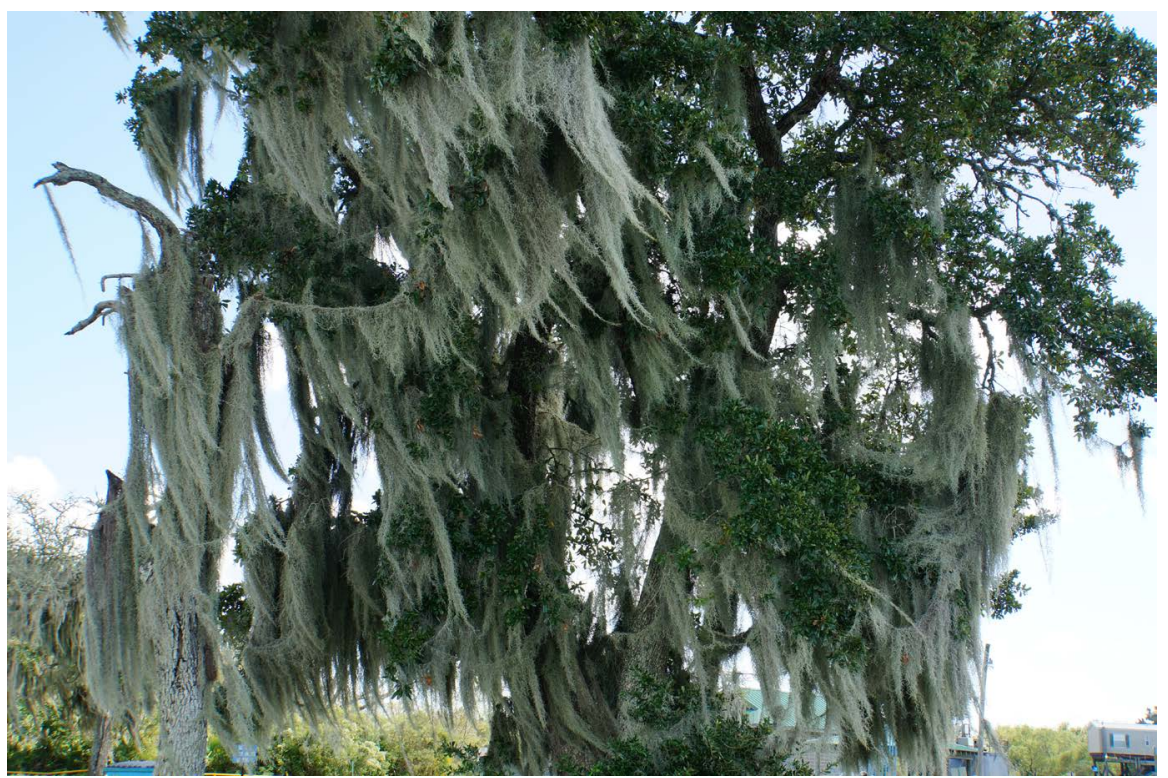

Figure 24. Spanish moss (Tillandsia usneoides) growing on southern oak trees (Quercus virginiana) near the Gulf of Mexico photograph taken by Lois Wright Morton.

The Mississippi River Gulf Outlet (MRGO), built in 1960s between the Port of New Orleans and the Gulf of Mexico, appears to have contributed to the loss of 10,914 ha by allowing salt water to enter freshwater ecosystems. The MRGO may have served as a "funnel" for Hurricane Katina storm surges, and may also have contributed to flooding in the Lower Ninth Ward in New Orleans and St. Bernard.

Dams and reservoirs on the sediment-rich Missouri River [21] and the other Mississippi River tributaries have reduced the sediment load of the Lower Mississippi River. Since the 1950s, these structures have reduced the sediment load 


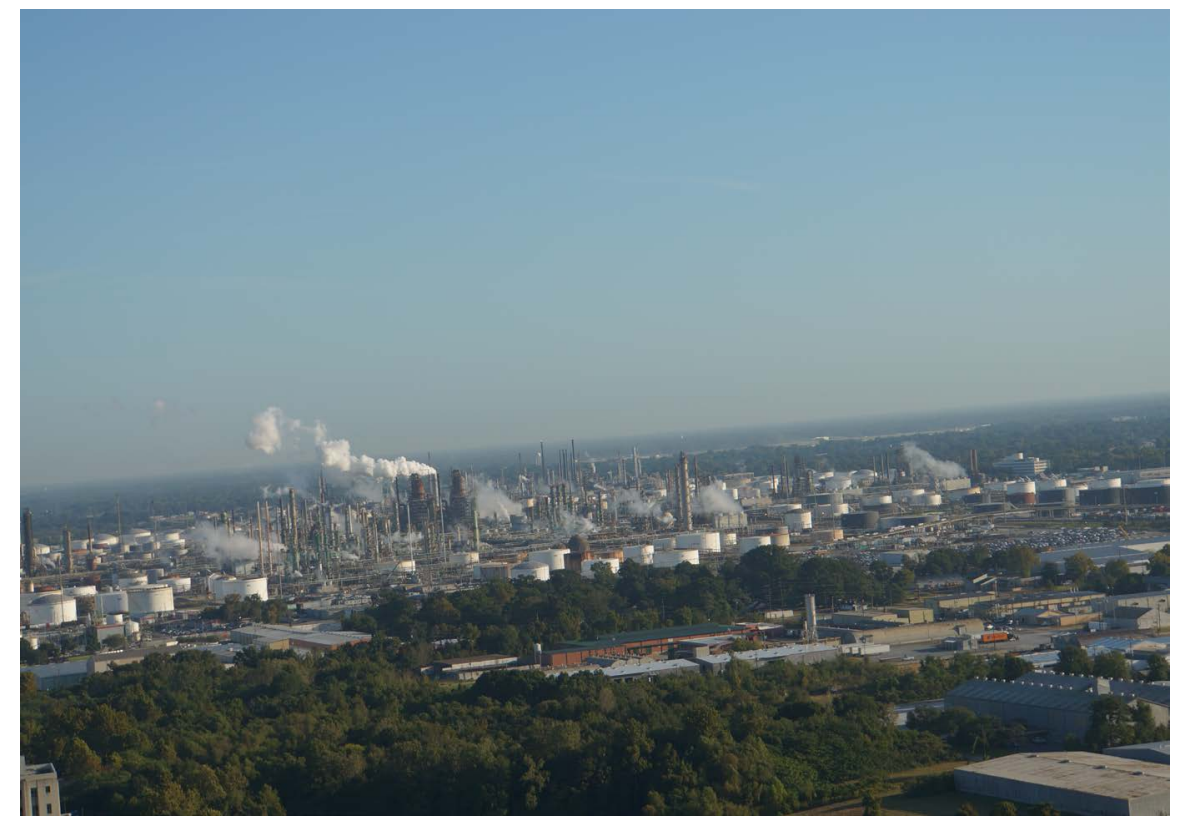

Figure 25. Oil and gas facilities on the Mississippi River Delta photograph taken by Lois Wright Morton.

by $50 \%$ [15]. The structures trap and block the rivers' land-building sediment, and cut the replenishment of nutrients and minerals needed by the Delta's ecosystems. Sediment diversions can be operated constructed and located to maximize the sediment carried to sediment-starved wetlands. Diversion can create new lands and strengthen existing wetlands.

The Atchafalaya River Basin, a river swamp, has an excess of sediment. Plans call for sediment in Atchafalaya basin to be re-distributed across the Louisiana coast. Delta growth occurred during the 1973 Mississippi River flood and has grown over the years to $29 \mathrm{~km}^{2}$.

The 2012 Louisiana Coastal Protection and Restoration [25] 50-year plan proposes a $\$ 50$ billion to save Louisiana's coast. The plan outlines 109 projects intended to bring long-term benefits such as resiliency and provide sustainability to the communities and ecosystems along the coast. Projects include sediment diversions, hydrologic restoration, barrier island restoration and marsh creation.

The Mid-Barataria Sediment Diversion is designed to address land loss and bring resilience and sustainability to the wetlands, preventing future loss and preserving critical ecosystems. The Resources and Ecosystems Sustainability, Tourist Opportunities and revived economies of Gulf Coast States Act (RESTORE) of 2012 followed BP's Deepwater Horizon oil spill of 2010, whereby $80 \%$ of BP fines were directed to 5 Gulf Coast states and the Gulf Ecosystem Restoration Council for environmental and economic restoration.

The Mississippi River suspended sediment concentration decreased between 1950 and 1966 (before the construction of 6 dams on the "Big Muddy" Missouri River) [21]. Since then, observed decreases in the suspended sediment load has been minimal, even with the use of reduced tillage and no till conservation prac- 
tices after 1966. The 1951 sediment load was $1,429,700 \mathrm{mt} /$ day, but in 1988 , it fell to $198,700 \mathrm{mt} /$ day. Between 1974 and 1990, the land loss rate in the Mississippi River Delta was $430 \mathrm{ha} / \mathrm{yr}$. This loss is a result of compaction, hurricanes, subsidence, sea rise, tidal erosion, and human activities including navigation channels and construction as canals for mineral extraction. Human activities include Mississippi River levees to the north and associated erosion control and channel stabilized measures, which prevent natural occurring crevasses or changes in the river's courses [1].

\subsection{Case Study: Sediment Needed in Coastal Zones}

Sediment is considered the key to managing river-dominated coastal zones. Previously, the sediment from the Lower Mississippi River was transported into the deep waters of the Gulf of Mexico [15]. However, now 50\% of the sediment load passes the major discharging outlets after these sediments settle out of the river's water column and aggrade (add sediment) to the channel floor [16].

In the $19^{\text {th }}$ century, the Mississippi River channel dynamics shifted from a plentiful sediment supply to a supply-limited system. This shift resulted in the Mississippi River channel south of the confluence of the Ohio and Mississippi rivers becoming a natural, self-scouring system [17]. This shift resulted in a shortening of the river, increased velocities and adding levees that limited overbanking and enhanced sediment export. Shoaling where a river channel becomes shallower is occurring. Shoaling reduces the slope of the Mississippi River or if changes in the volume of water carried by the river's distributaries occur and increases when sea levels rise. Both scenarios could affect navigation and commerce (Figure 26 and Figure 27).

An important policy objective is restoring the Mississippi River Delta and adjacent environments. The Mississippi River Delta is a major center for human

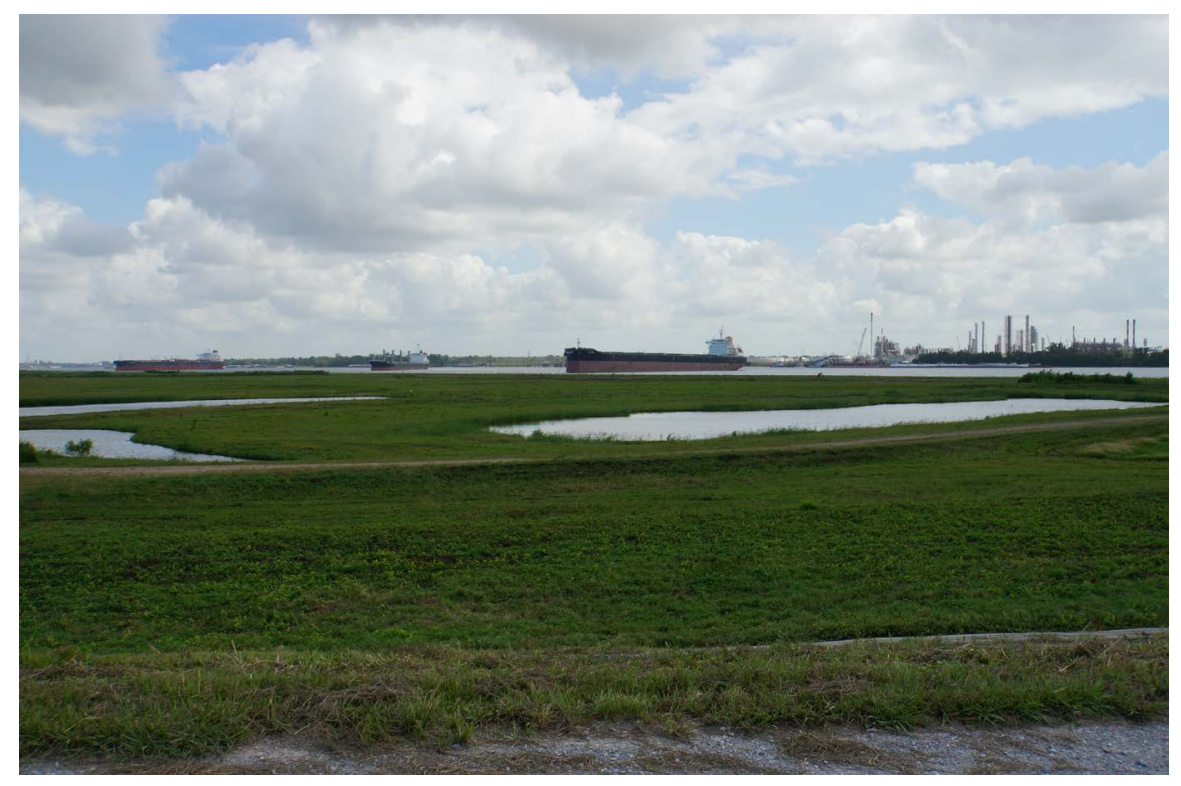

Figure 26. Deep draft ships on the Mississippi River near Bonnet Carre. 


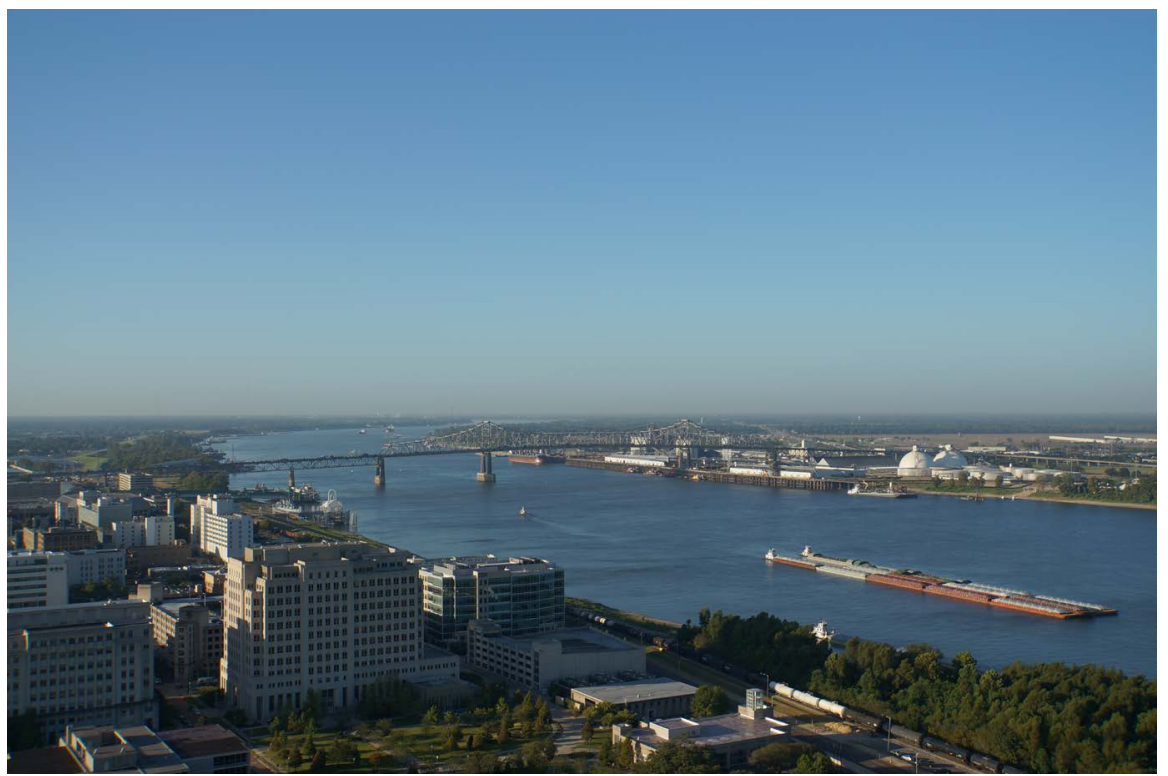

Figure 27. Barges and ships on the Mississippi River at Baton Rouge

population, transportation, industry and ecosystem services [24]. River diversions are proposed in Louisiana's Coastal Master plan [20]. Critical aspects of this plan include navigation [25], energy production, fisheries, salinity, water quality, restoration of damaged habitats and flood protection of coastal communities. Coastal restoration plans rely in part on diverting a portion of the river flow to bring freshwater and new sediments into the subsiding basin [18] [19]. Flow through gated and controlled diversions can reduce adverse impacts such as shoaling and eutrophication and maximize land building. Complex environmental management in great river systems requires broad-based complex science, monitoring and engineering [25].

\section{Summary and Conclusions}

The lack of sediments can be attributed to conservation practices on the uplands in the Mississippi River basin, levee systems including dikes and weirs, earthen levees and navigation channels. Many of the structures slow or eliminate the Mississippi River flow to bottomland and marsh areas and increasing saltwater intrusion from the Gulf of Mexico into freshwater wetlands.

Measures to accommodate deep-draft navigation, such as dredging, are needed between the Mississippi River and the Gulf of Mexico. Any reduction in the flow of the Mississippi River will result in an increase in dredging requirements and a reduction of the depth of naturally occurring channels. The need for oil and gas for national security is also a national priority but appears to be contributing to the subsidence. Sediment collected in the 6 huge Missouri river reservoirs reduces the Lower Mississippi sediment load. In addition, there is a need to cut soil loss from erosion on the North Central uplands and reduce transport to the streams in the Mississippi River Valley. This has resulted in the reduction of the sediment load of the major tributaries to the Lower Mississippi 
River, including the Missouri, Upper Mississippi and Illinois rivers and their tributaries. The jury is still out on the use of the thousands of dikes and weirs on the Mississippi and Missouri rivers and their tributaries, which appear to sustain the navigation river channels but contribute to moving the sediment load to the Gulf of Mexico via suspension and dispersion.

The Mississippi River Delta shoreline is eroding and significant land areas and wetlands are being converted to open water. The wetlands and landmasses are also subsiding as a result of oil and gas extraction, consolidation, and reduced sediment loads in the lower Mississippi and Missouri rivers as a result of the use of 13,000 weirs and dikes that create turbulence and keep sediment in suspension into the Gulf of Mexico. These activities should help restore critical habitat for many commercially important marine fisheries, and ensure sustainability into the future.

The USACE is trying to mitigate by adding sediment to existing Lower Mississippi River wetlands by creating conditions similar to the Atchafalaya River Delta. A USACE plan is needed if any attempt is made to preserve the existing shoreline and wetlands that buffer future storm surges. The object of stabilizing the existing delta and marshes is a secondary concern. Attempts to stabilize the current shoreline will require the partnering with two major land owners the U.S. Fish and Wildlife Service (USFWS) and the Louisiana Department of Wildlife and Fisheries (LDWF). Additional mitigation attempts are needed to address the loss of wetlands and shorelines.

\section{Acknowledgements}

This paper is published with funding support from USDA, NIFA, Water Division and Department of Natural Resources and Environmental Sciences and with the approval of the Director of the Illinois Office of Research, College of Agricultural, Consumer, and Environmental Science, University of Illinois, Urbana, Illinois.

\section{Conflicts of Interest}

The authors declare no conflicts of interest regarding the publication of this paper.

\section{References}

[1] Olson, K.R. and Morton, L.W. (2016) Managing the Mississippi and Ohio River Landscapes. Soil and Water Conservation Society, Ankeny.

[2] Törnqvist, T.E., Wallace, D.J., et al. (2008) Mississippi Delta Subsidence Primarily Caused by Compaction of Holocene Strata. Nature Geoscience, 1, 173-176. https://doi.org/10.1038/ngeo129

[3] Roberts, H.H. (1997) Dynamic Changes of the Holocene Mississippi River Delta Plain: The Delta Cycle. The Journal of Coastal Research, 13, 605-627.

[4] Coleman, J.M., Roberts, H.H. and Stone, G.W. (1998) Mississippi River Delta: An Overview. Journal of Coastal Research, 14, 898-716. 
[5] Blum, M.D. and Roberts H.H. (2012) The Mississippi Delta Region: Past, Present and Future. Annual Review of Earth and Planetary Sciences, 40, 655-683. https://doi.org/10.1146/annurev-earth-042711-105248

[6] Bernard, S.K. (2016) A History of Louisiana's Most Famous Bayou. Louisiana Endowment for Humanities, USA.

[7] Olson K.R. and Suski, C.D. (2020) St. Lawrence Seaway: Navigation of Gulf of Saint Lawrence Estuary and the St. Lawrence River. Journal of Water Resource and Protection, 12, 972-691.https://doi.org/10.4236/jwarp.2020.128041

[8] Blum, M.D. and Roberts, H.H. (2009) Drowning the Mississippi Delta Due to Insufficient Sediment Supply and Global Sea-Level Rise. Nature Geoscience, 2, 488-491. https://doi.org/10.1038/ngeo553

[9] Chesney, E.J., Baltz, D.M. and Thomas, R.G. (2000) Louisiana Estuarine and Coastal Fisheries and Habitats: Perspectives from a Fish's Eye View. Ecological Applications, 10, 350-366. https://doi.org/10.1890/1051-0761(2000)010[0350:LEACFA]2.0.CO;2

[10] Peterson, M.S. (2003) A Conceptual View of Environment-Habitat-Production Linkages in Tidal River Estuaries. Reviews in Fisheries Science, 11, 291-313. https://doi.org/10.1080/10641260390255844

[11] Rose, K.A., Huang, H., Justic, D. and de Mutsert, K. (2014) Simulating Fish Movement Responses to and Potential Salinity Stress from Large-Scale River Diversions. Marine and Coastal Fisheries, 6, 43-61. https://doi.org/10.1080/19425120.2013.866999

[12] James Jr, H., Deegan, L.A. and Day, J.W. (2014) Fisheries in a Changing Delta. In: Day, J., Kemp, G., Freeman, A. and Muth, D., Eds., Perspectives on the Restoration of the Mississippi Delta, Springer, Dordrecht, 99-109. https://doi.org/10.1007/978-94-017-8733-8_7

[13] Kemp, G.P., Day, J.W. and Freeman, A.M. (2014) Restoring the Sustainability of the Mississippi River Delta. Ecological engineering, 65, 131-146. https://doi.org/10.1016/j.ecoleng.2013.09.055

[14] de Mutsert, K., Lewis, K., Milroy, S., Buszowski, J. and Steenbeek, J. (2017) Using Ecosystem Modeling to Evaluate Trade-Offs in Coastal Management: Effects of Large-Scale River Diversions on Fish and Fisheries. Ecological Modelling, 360, 14-26. https://doi.org/10.1016/j.ecolmodel.2017.06.029

[15] Allison, M.A., De Mas, C.R., Ebersole, B.A., Kleiss, B.A. and Little, D. (2012) A Water and Sediment Budget for the Lower Mississippi-Atchfalaya River in Flood Years 2008-2010: Implications for Sediment Discharge to Oceans and Coastal Restoration in Louisiana. Journal of Hydrology, 432-433, 84-97. https://doi.org/10.1016/j.jhydrol.2012.02.020

[16] Little, C.D. and Biedenharn, D.S. (2014) Mississippi River Hydrodynamic and Delta Management Study-Geomorphic Assessment, Final Report. Rep. ERDC/CHL TR-14-5. Engineering, Research and Development Center, Vicksburg, Mississippi.

[17] Alexander, J.S., Wilson, R.C. and Green, W.R. (2012) A Brief History and Summary of the Effects of River Engineering and Dams on the Mississippi River System and Delta. United States Geological Survey, Circular 1375, 43 p. https://doi.org/10.3133/cir1375

[18] Fisk, H.N., et al. (1954) Sediment Framework of the Modern Mississippi Delta. Journal of Sedimentary Petrology, 24, 76-99. https://doi.org/10.1306/D4269661-2B26-11D7-8648000102C1865D

[19] Twilley, R.R., et al. (2016) Co-Evolution of Wetland Landscapes, Flooding and Hu- 
man Settlement in the Mississippi River Delta Plain. Sustainability Science, 11, 711-731. https://doi.org/10.1007/s11625-016-0374-4

[20] Esposito, C.R., Georgiou, I.Y. and Kolker, A.S. (2013) Hydrodynamic and Geomorphic Controls in Mouth Bar Evolution. Geophysics Research Letter, 40, 1540-1545. https://doi.org/10.1002/grl.50333

[21] Olson, K.R. and Morton, L.W. (2017) Managing the Upper Missouri River for Agriculture, Irrigation, Flood Control, and Energy. Journal of Soil and Water Conservation, 72, 105A-110A. https://doi.org/10.2489/jswc.72.5.105A

[22] Water Resource Development Act (2007) Bill Summary and Status. Library of Congress, USA.

[23] Barras, J.A. (2005) Land Area Changes in Coastal Louisiana after Hurricanes Katrina and Rita, Science and the Storms: the USGS. Response to hurricanes of 2005. United States Geological Survey, Circular 1306, 97-112. https://doi.org/10.3133/cir13065B

[24] Louisiana Coastal Protection and Restoration Authority (LACPRA) (2017) Louisiana's Comprehensive Master Plan for a Sustainable Coast. Coastal Protection and Restoration Authority, Baton Rouge, LA.

[25] Olson, K.R. and Speidel, D.R. (2020). Why Does the Repaired Len Small Levee, Alexander County, Illinois, US Continue to Breach during Major Flood Events? Open Journal of Soil Science, 10, 16-43. https://doi.org/10.4236/ojss.2020.101002 